\title{
Lithospheric framework of the Indian sub-continent through Seismic and Seismological Studies
}

\author{
1. E-57, Judge Farm, Haldwani-263139, India, ramaharish1@gmail.com \\ 2. CSIR - National Geophysical Research Institute, Hyderabad-500007 India, Email: pk.ngri.csir@gmail.com
}

(Received : 27/05/2019; Revised accepted : 13/10/2019)

https://doi.org/10.18814/epiiugs/2020/020041

Knowledge of the crust and lithospheric structure of the Indian sub-continent primarily comes from several active and passive seismic experiments. These studies are i) controlled source, ii) surface wave studies, iii) receiver functions and v) tomographic studies. The results from these studies in the Indian shield have emanated several interesting features that were hitherto unknown. The peninsular, central and north-western part of the shields, Himalayan and Andaman-Nicobar regions have shown that continental collision and extension from the Proterozoic to Recent time has played an important role in formation and geodynamics of these features. The granulites, in the southern granulite terrain, are formed primarily due to the release of the carbonic fluids from the supracrustal rocks of the subduction zone and volcanic arc environment. These were later exhumed from the deep crust during the collision process. In the central Indian shield the Narmada-Son lineament and the central Indian suture are the main features of the crust. In the Narmada region, mafic intrusion in the upper crust appears to have played an important role in shaping the present structural trends. The Central Indian suture is a collision zone developed due to the interaction of the Bastar and Bundelkhand cratons. In the northwesternpart of the India, the Aravalli-Delhi trend is the controlling feature for the tectonics of the region. Demarcation of the various boundaries between different crustal units are marked across the trend, by changes in the dip direction and steeply dipping reflections, cutting across the nearly horizontal reflections at various depths in the crust. Plate tectonics appears to be responsible for generation of this belt. In the crustal block between the Delhi-Aravalli system and the Narmada-Son Lineament, which is running to the south of the Saurashtra peninsula the crust up uplifted by as much as 4 to $6 \mathrm{~km}$ as compared to the regions outside these trends.

Apart from the deep crustal structure, lithospheric and upper mantle studies till $660 \mathrm{~km}$ depth have also been conducted in the entire Indian plate using seismological tools e.g. P-to-s and S-to-p receiver function, surface waves dispersion and tomographic studies. The Himalayan region shows the architecture of the under thrusting Indian plate beneath the Tibetan plate in the north and north-west, while the subduction beneath the Burmese arc has been mapped in the eastern part. Further, a number of studies have been conducted in the Andaman-Nicobar Islands to image the subduction of Indian oceanic plate in order to understand the genesis of earthquakes in these regions.

\section{Introduction}

Studies of the Earth's structure have proven that the Earth consists of several layers consisting mainly of four units: the inner core, outer core, mantle, and lithosphere. The lithosphere can be further divided into crust and mantle lid. The crust and the uppermost mantle, which forms the lithosphere, extends about 70-100 km under the deep ocean basins and 100-200 km under the continents. It is a rigid and hardouter shell that deforms in an essentially elastic manner. The crust is the Earth's hard outer shell and is thinner compared to other layers of the Earth.

Global studies on crustal thickness reveal that nature of the crustmantle discontinuity (i.e. Moho) is quite variable throughout the different tectonic regions. At a few places, it is a sharp, whereas at most of the other places it is diffused in nature. Seismically, refraction phases $\left(\mathrm{P}_{\mathrm{n}}\right.$ and $\mathrm{S}_{\mathrm{n}}$ ) constrain the velocity contrast across the Moho. The seismic characteristics of Archean, Proterozoic and Phanerozoic crust are different over the geologic time as they evolved in different geological environment (Meissner, 1986) and therefore crustal thickness varies through the tectonic regions. While the continental crust is $30-70 \mathrm{~km}$ thick, the oceanic crustal thickness is $6-12 \mathrm{~km}$. The oceanic crust is also denser (density: $2.8-3.0 \mathrm{~g} / \mathrm{cm}^{3}$ ) than the 
continental crust $\left(2.6-2.7 \mathrm{~g} / \mathrm{cm}^{3}\right)$. The average Archean crust is $\sim 35 \mathrm{~km}$ thick, whereas the Proterozoic crust is significantly thicker ( $\sim 5 \mathrm{~km}$ ). A number of models exist to describe the global crust in diverse geological terrains.

The structural features that developed in the crust of Precambrian terranes show that they have persisted in several regions. This means that this crust, along with the upper mantle, has remained coherent throughout. The velocity models for the crust of Proterozoic and Archaean terranes of the world have shown that the distribution of velocity in these two terranes is significantly different from each other. As compared to crustal thickness of 27-40 km (except at collision boundaries) in the Archaean terrane, the Proterozoic crust has a greater thickness (40-45 km) (Durheim and Mooney, 1994). The Proterozoic crust has a thick high velocity $\left(>7.0 \mathrm{kms}^{-1}\right)$ layer at its base that is absent in most of the Archaean terrane. Thickness of the high velocity layer is a major factor of difference even within the Proterozoic terranes. Most of the Archaean terranes are sharp, distinctive crustmantle boundaries at about 35-40 km depth and the velocity in the lower crust is less than $7.0 \mathrm{kms}^{-1}$. The crust building processes during the two periods are also different to each other.
The crust of the Indian shield is heterogeneous in nature. As the shield is a mosaic of diverse terranes having the imprints of various tectonic episodes in geological history, from Archean to the NeoProterozoic. Here, continental collision and extension have taken place during several episodes. The geological history of the earlier episodes (from Archaean to Triassic) is not well documented, whereas those from the Triassic to the Quaternary is much better understood. Major rifting episode split the then existing Gondwanaland into two parts: East and West Gondwanaland, during the Triassic. The two parts of the Gondwanaland and the oceanic crust between them were together till the Jurassic. The Indian continent, Antarctica and Australia were together in the East Gondwanaland. In the early Cretaceous the Indian subcontinent broke off from Antarctica and Australia and the Indian Ocean opened up. the Indian plate started its Very rapid northward drift of the Indian plate, at an average speed of $16 \mathrm{cmyr}^{-1}$, started during the upper Cretaceous. It covered a distance of about $6000 \mathrm{~km}$ and a rotation of $33^{\circ}$ in an anticlockwise direction, until the northwestern part of the Indian passive margin collided with Eurasia in Early Eocene. Northward drift of the Indian plate is still continuing at a slower but still surprisingly fast rate of about $5 \mathrm{cmyr}^{-1}$. Various cratons of the Indian plate are separated from each other by mobile belts (Fig. 1) in its shield region (Vijaya Rao and Reddy, 2002).

To understand the geological history of the Indian plate crustal studies were carried out in its various geological terrains. These consisted of seismic refraction and wide-angle reflection studies along various profiles. Deep seismic reflection data were also acquired in some of the terranes (Aravalli-Delhi fold belt, central India, Southern Granulite Terrane, Himalayan foothills like HIMPROB).

Interpretation of these data resulted in the form of crustal velocity configuration and structure down to the Moho boundary, and also in the uppermost mantle in a few instances. This has helped in understanding the evolutionary processes involved in the formation of these terranes. The results of the southern, central and part of the Indian shield regions and surrounding regions are described in this paper. The last section deals with the lithospheric thickness of the Indian plate using seismological methods.

\section{South Indian Peninsular Shield}

Crustal blocks of independent evolutionary history form the South Indian peninsular shield, some of the exposed rocks being as old as $3800 \mathrm{Ma}$ (Rao et al., 1991; Naha et al., 1991). The 


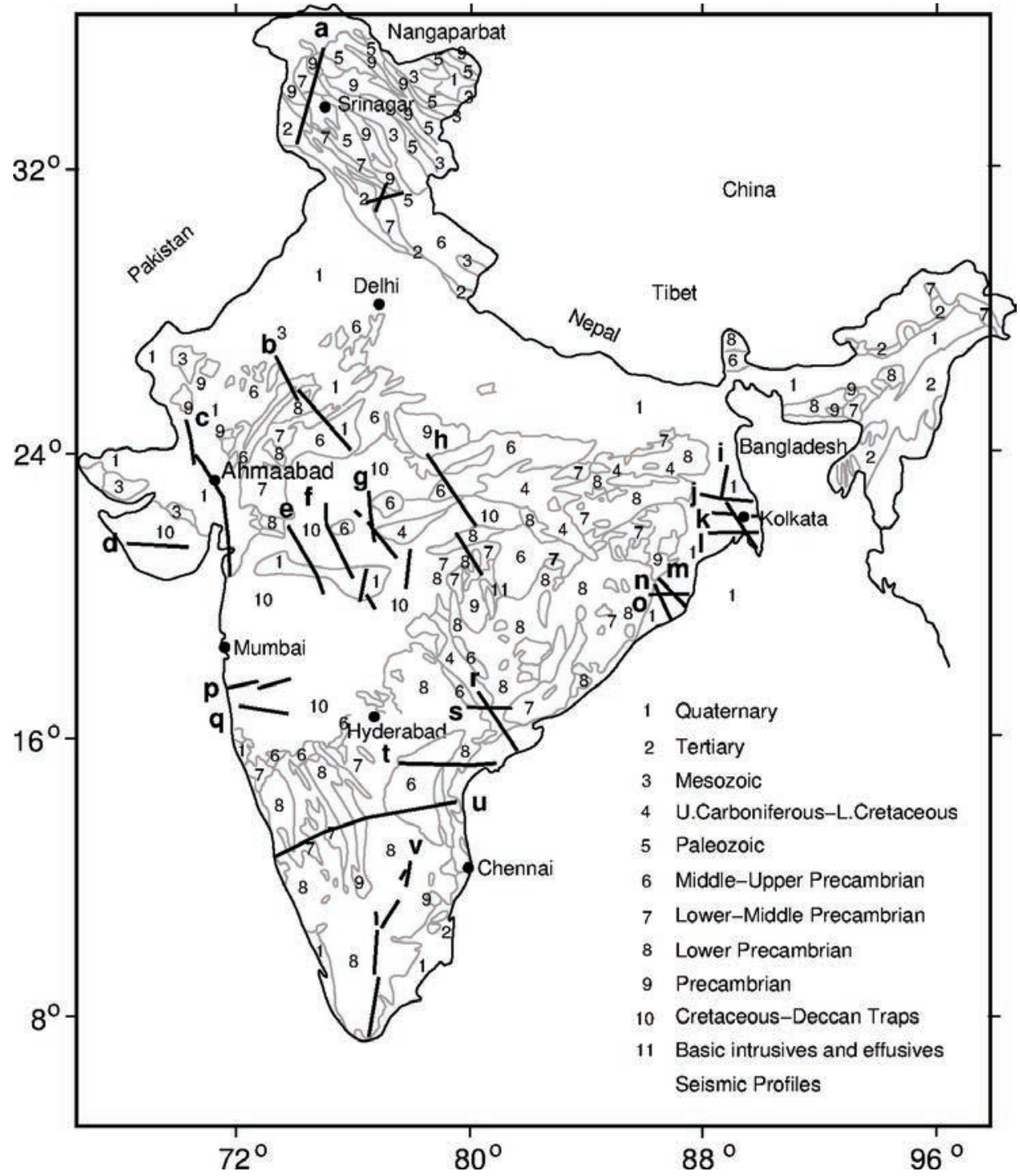

Figure 2. Map showing the location of DSS profiles in India. The names of the profile is shown by bold alphabets. The place names start from the side of the alphabets are written e.g. a: Nangaparbat - Naoshera, b: Nagaur - Nandsi, c: Dharimann - Billimora, d: NavobandarAmreli, e: Thuadara - Sindad, f: Ujjain - Mahan, g: Khajuriakalan - Pulgaon, h: Hirapur Mandla, i: Kandi-Portcanning, j: Beliaton - Bangaon, $k$ - Arambag - Raki, l - Gopalk Portcanning, m - Kabatabandha - Paradip, n: Mukundpur - Konarak, o: Balimba Jagannathpur, p: Kelsi - Loni, q: Guhagar - Chorochi, r: Paloncha - Narsapur, s: Kallu Polavaram, t: Kurnool - Ganapeswaram, u: Kavali - Udipi, v: Kuppam - Kanyakumari.

the two is caracterized by an exposed granitic belt. The western craton is dominated by greenstone belts with subordinate volcanism and metamorphism with intermediate pressure. Whiel the eastern Dharwar craton has greenstone belt with low presurrue metamorphism. The northen block of Dharwar craton is dominated by tonalitetrondhjemite-granodiorite (TTG) gneisses which frequently refere as the Peninsular gneisses. The geochronological data indicate that the accretio of TTG occurred at about 3.4 Ga, 3.3-3.2 Ga and 3.0-2.9 Ga (Meen et al., 1992). The eastern part of east Dharwar craton lies Proterozoin Cuddapah basin. The Cuddapah basin (Figure 3a) contains unmetamorphosed sediments and a number of intrusive/extrusive bodies of basic igneous rocks in a tectonic and orogenic belt of fossiliferous Proterozoic rocks. The basin has the following structural trends: (i) a low amplitude, asymmetrical syncline that plunges north and is made up of gently dipping, practically unfolded western limb where unmetamorphosed Palaeoproterozoic sediments of lower Cuddapah and Neoproterozoic Kurnool system are exposed and (ii) an eastern limb that is intensely folded and thrusted and contains Neoproterozoic upper Cuddapah sediments and several domes shaped up warps (Narayanaswamy, 1966). The western and eastern limbs of this basin are separated by a fault. Here the upper Cuddapah formation thrusts over the younger Kurnool formation. The western part of the basin consists volcanic rocks that are exposed. The Cuddapah group of rocks comes into contact with the Dharwar group (Archaean-Preterozoic) beyond the eastern margin of the basin.

northern part consists of the low-grade granite-greenstone of the Dharwar craton and the southern part has high-grade granulite terrane. To determine the crustal configuration of the crust in the Indian peninsular shield, refraction and post-critical reflection studies were carried out along two east-west profiles, across the ProterozoicArchean Cuddapah Basin and the Dharwar craton. Refraction, postcritical reflection and deep reflection studies were also carried out along a profile crossing the southern granulite terrane (including the Cauvery shear zone) in a north-south direction.

\section{Dharwar Craton}

The geologically Dharwar craton can be classified into two main tectonic units viz. western Dharwar craton and eastern (Figure 3) Dharwar craton (Ramakrishnan et al., 1976). The demarcation between
The 600-km long Kavali-Udipi profile (Profile I, Figure 3b), recorded through seismic refraction/post-critical reflection studies during the years 1972-75, was the first attempt in India to study the crust seismically. This profile cuts across several Proterozoic and Archaean geological terranes of Eastern Ghat, eastern and western Dharwar cratons. The Cuddapah basin is a major geological feature in the eastern Dharwar craton. Another 300-km long Alampur-Koniki east-west profile (Profile II of Figure 3b) traversing the northern part of the Cuddapah basin was also recorded similarly. Figure 4 represents the velocity-depth models of crust across the south Indian shield.

\section{Southern Granulte Terrain}

Lower crustal rocks are exposed in the Southern Granulite Terrane of India (Figure 5). It is one of the few terranes in the world that has 
a)

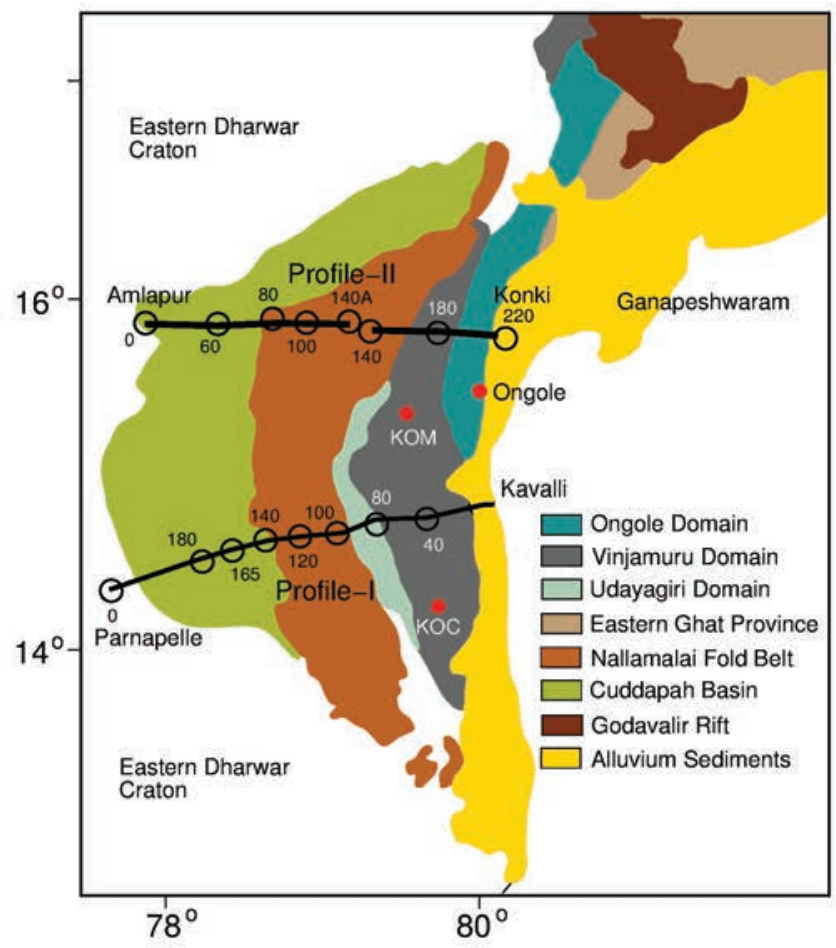

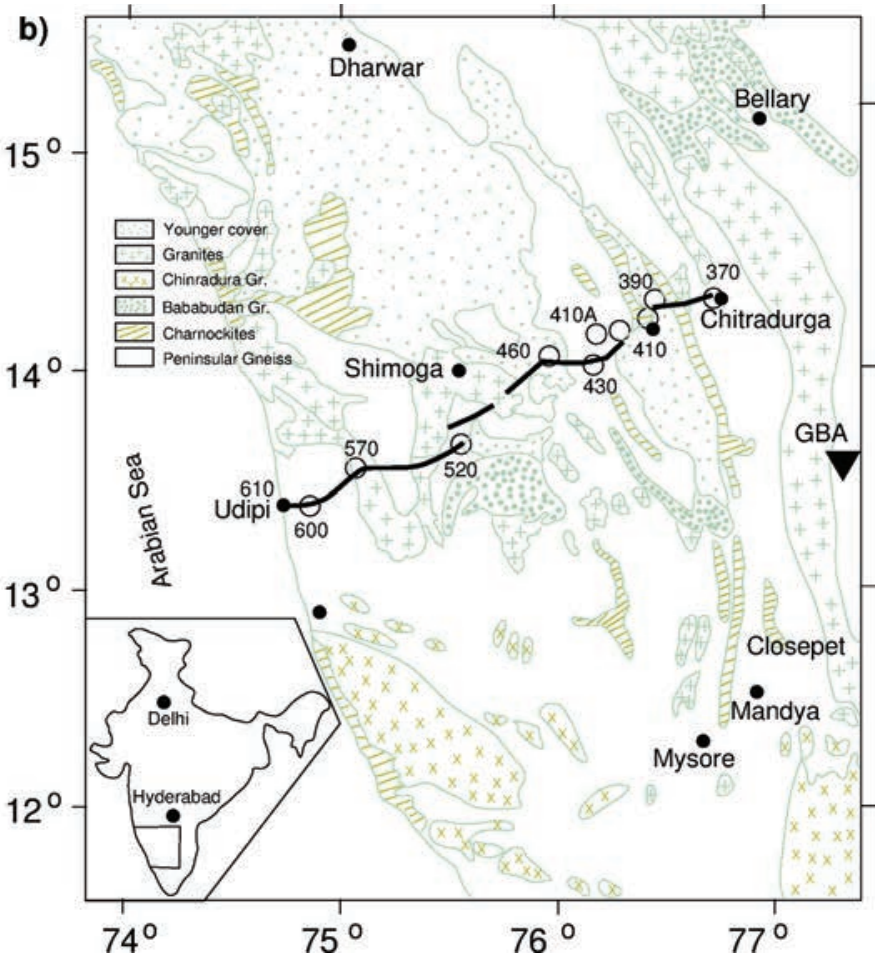

Figure 3. Geological map of a) the Cuddapah basin and area to its east (after Kaila et al., 1987) b) Dharwar craton (after Kaila et al., 1979) with deep seismic profiles.
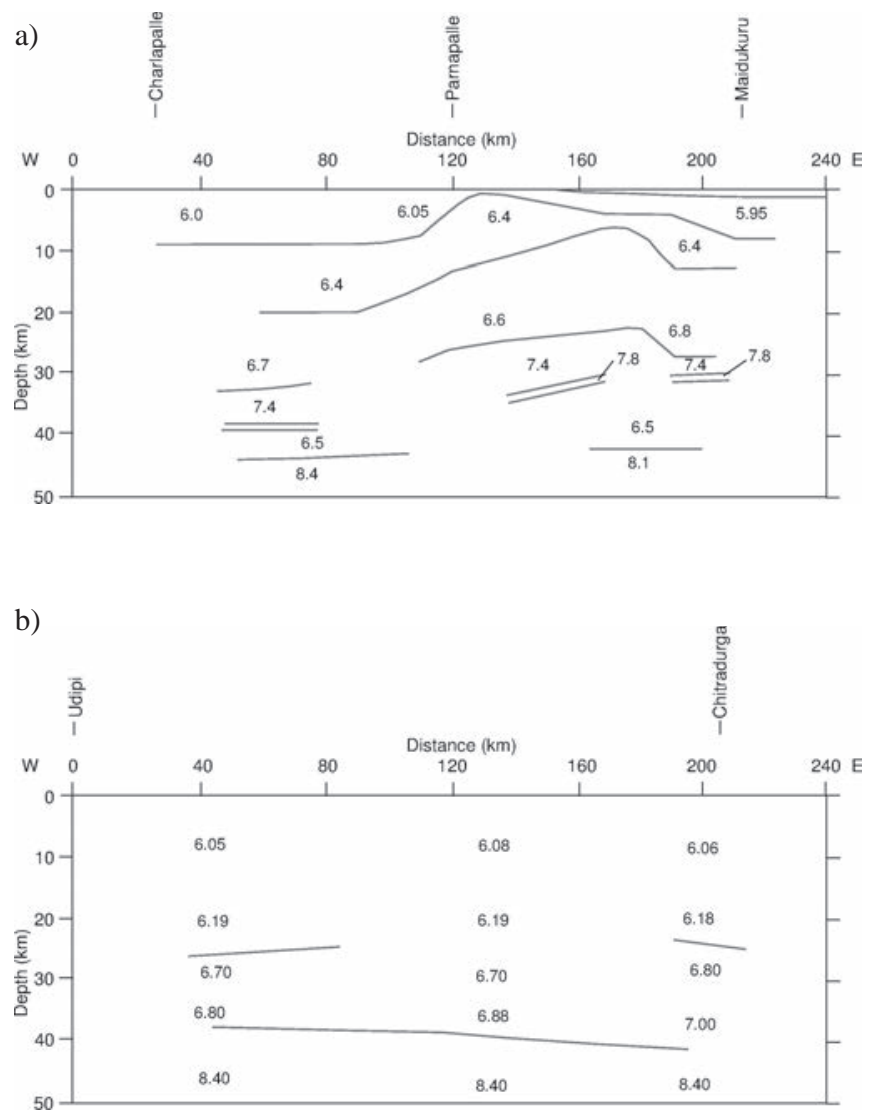

Figure 4. Velocity ( $\mathrm{kms}^{-1}$ ) - Depth model for a) the Cuddapah basinn (Reddy et al., 2004) (Profile II in Figure 2a); b) Dharwar craton (Sarkar et al. 2001). Velocity values are in $\mathrm{kms}^{-1}$. preserved the Archaean crust. The granulite is formed at an average pressure and temperature of $7-10 \mathrm{kbar}$ and $700-800^{\circ} \mathrm{C}$ respectively. The mantle heat flow has also been reprted higher (Ray et al., 2003). It corresponds to burial depths of about 20-25 km and represents rocks from the deep crust. These rocks, often formed by thickening in older terranes, are uplifted to the surface by various mechanisms. Various models have been given to explain the tectonic emplacement of these rocks in the Indian peninsular shield. These include subduction, collision and accretion of micro terranes, flower structure and transtensional tectonics. Figure 6 represents the velocity-depth model across this terrane.

The reflection results indicate a collision of the Dharwar craton and another block in the south which is a part of the present eastern ghat mobile belt. These two crustal blocks are separated by a volcanic arc. This led to thickening of the crust in contact zone of the eastern Dharwar craton and Moyar-Bhavani shear zone. The granulites were formed due to release of carbonic fluids from the supracrustal rocks of the subduction zone in a volcanic arc environment. Later during the collision process these were exhumed from the deep crust (Vijaya Rao et al., 2006).

A schematic model showing different stages for evolution of crust in the Cauvery shear zone system (Figure 7) has been built by Vijaya Rao and Rajendra Prasad (2006). This model, based on the pressuretemperature conditions, petrological and geophysical results, shows that compressional forces brought the Dharwar craton and the southern block close to each other leading to collision during the late Archaean forming Moyar-Bhavani shear Zone / Mettur Shear Zone and Neoarchean ganulites (Vijaya Rao et al., 2006). The crust between these two blocks was thickened due to compressional forces operative at that time. The thickened crust became unstable and led to orogenic collapse under its own weight after the stoppage of these forces. The unstable layer finally peeled off and sank into the mantle as the crustal 


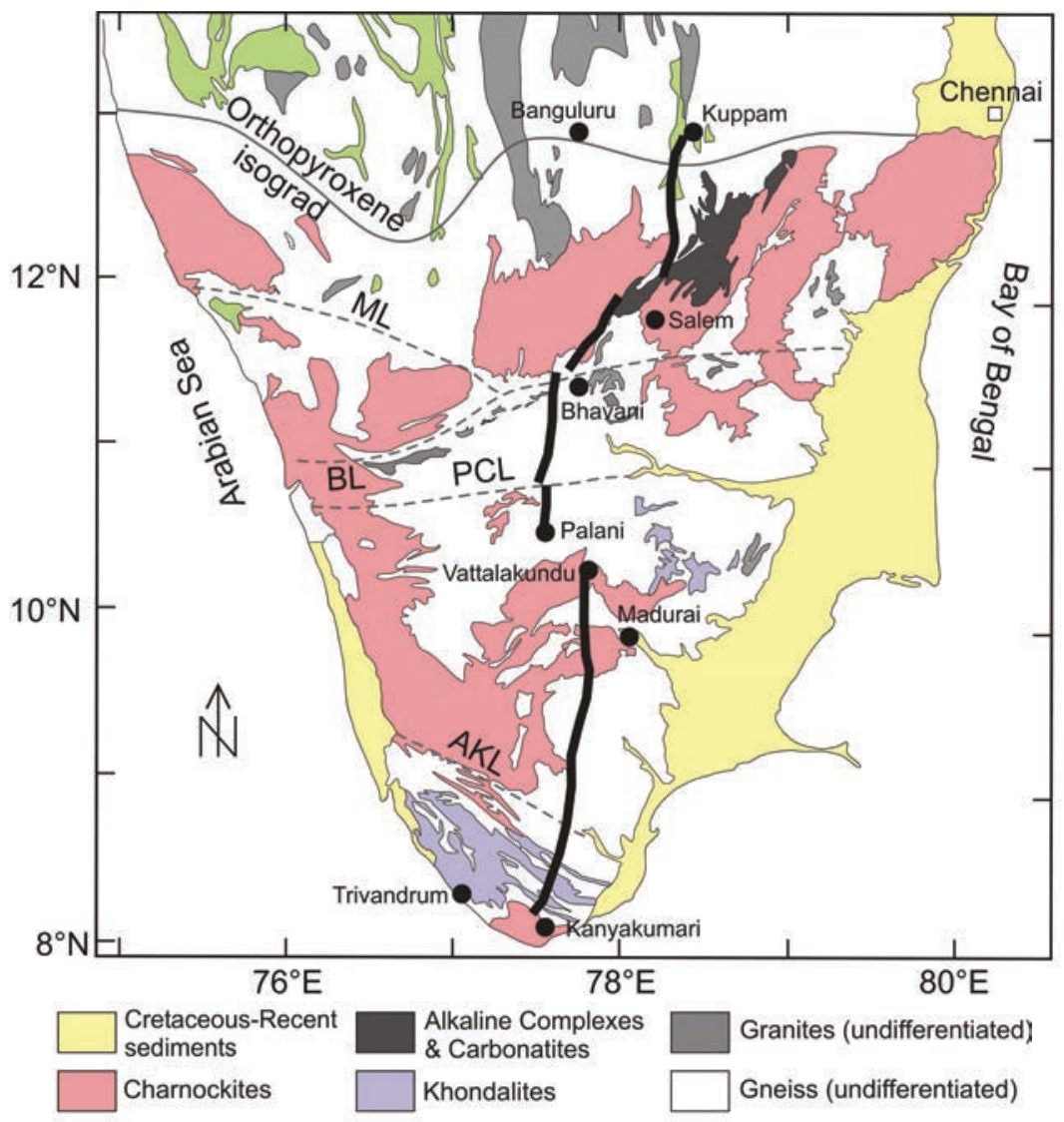

Archaean Greenstone Belts _--- Major Lineaments

Figure 5. Simplified tectonic map of south Indian shield. AKL: Achankovilshear Zone. PCL: Palghat-Cauvery shear Zone, EDC: Eastern Dharwar Craton, WDC: Western Dharwar Craton; KKB: Kerela Khondalite Block; BL:EGMB Eastern Ghat Mobile Belt; MB - Madurai block; ML and BL are Moyar and Vhavani Shear zones. (Chetty et al., 2003; Bhaskar Rao et al., 2003).
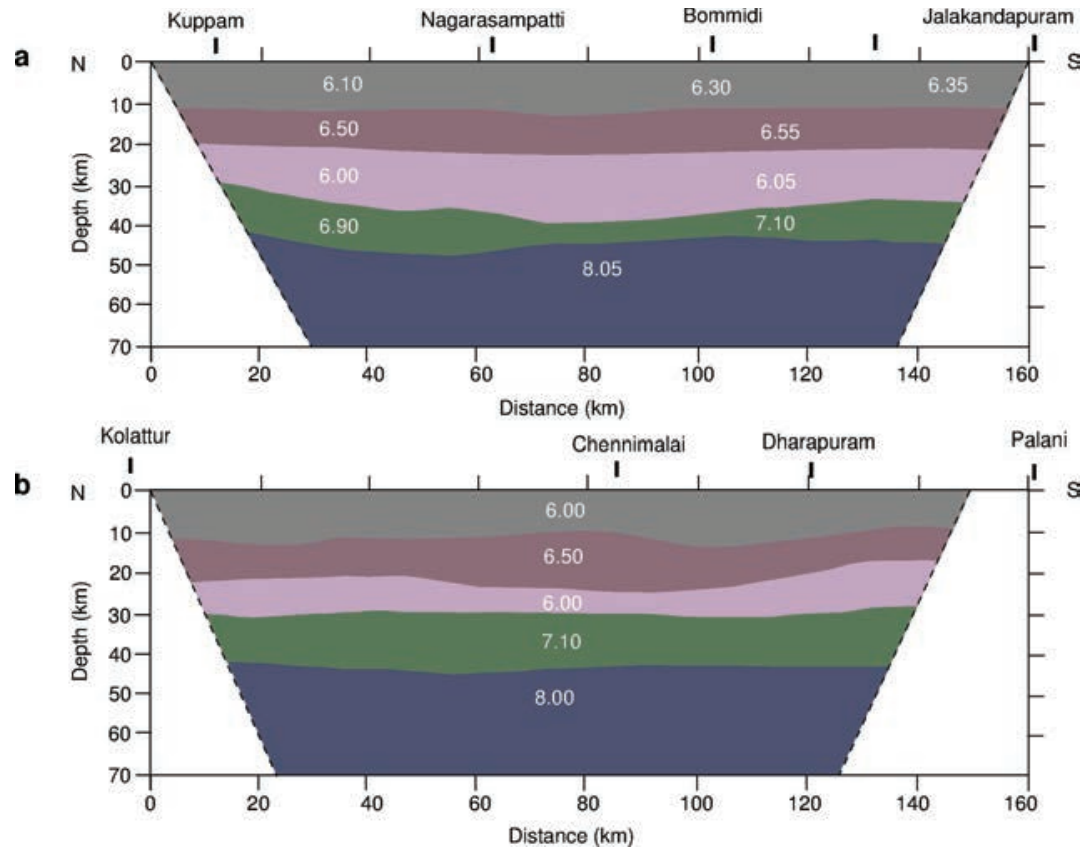

Figure 6. Velocity $\left(\mathrm{kms}^{-1}\right)$ - depth model for the crust along the Kuppam-Palani profile in southerngranulite terrane, (a) Kuppam-Kolattur, (b) Kolattur-Palani (Vijaya Rao et al., 2006). roots of a thickened crust become denser than the underlying mantle lithosphere, ultimately leading to its delamination. The delaminated lower crust of the region got modified due later tectonic activities. Surface manifestations of rifting of these zones is represented by alkaline rocks that are present between the MoyarBhavani and Karur-Oddanchatram shear Zones.

\section{The central Indian shield}

Four main tectonic units are present in the central part of the Indian shield (Figure 8). These are: 1 . The Bundelkhand craton (Late Archaean to Neoproterozoic), 2. The Satpura mobile belt (Palaeoproterozoic to Mesoproterozoic), 3. KotriDongargarh mobile belt (middle Archaean to Mesoproterozoic) and 4. The Bastar craton (Archaean). The Narmada-Son lineament and the central Indian suture are the other important tectonic elements of the region. To the west and south of these tectonic units lies the Dharwar craton. Late Archaean compression is a part of the tectonic history of the Bundelkhand craton. The Archaean gneiss, exposed in large part of this craton, includes migmatitic gneiss, older migmatitic enclaves, basement relicts as well as paragneiss. The Archaean assemblage has banded, streaky and augen gneisses, amphibolites and pillow volcanics. Amphibolites-facies metamorphism took place in this assemblage (Sarkar et al. 1981).

The velocity-depth configuration of the crust in this region was studied along four seismic profiles across the Narmada zone (Figure 9) and one across the central Indian suture (Figure 10).

The Barwani-Sukta fault has played a major role in development of the crust in this region is indicated by the seismic velocity-depth models of the crust along these profiles. The Narmada north and south faults divide the upper crust in a horst-graben structure to the east of this fault. The Narmada uplift in central India is represented by a low gravity axis that divides the region in two distinct parts, north and south of the Narmada region. Mafic intrusion in the upper crust has played a major role in shaping the present structural trends of the Narmada region. Displacement at the top of this layer, a result of repeated reactivation of the Narmada fault system, is observed along the three eastern profiles (Kumar et al., 2000; Tewari et al., 2001). Major crustal disturbances are confined in the upper crust. This could be because of two reasons; (a) either the Narmada north and south faults are prominent only down to the upper crust and die out with depth due to ductility of the lower crust or (b) relief on the lower crust and Moho was subsequently erased by the ductile flow, whereas the structures were preserved in the cooler crust above (Kumar, 2002; Kumar et al., 2000). The sub-crustal lithosphere in the central Indian region has varying structural and mechanical properties. This is indicated by upper mantle velocity model along one of the profiles, which shows a lamellar structure 


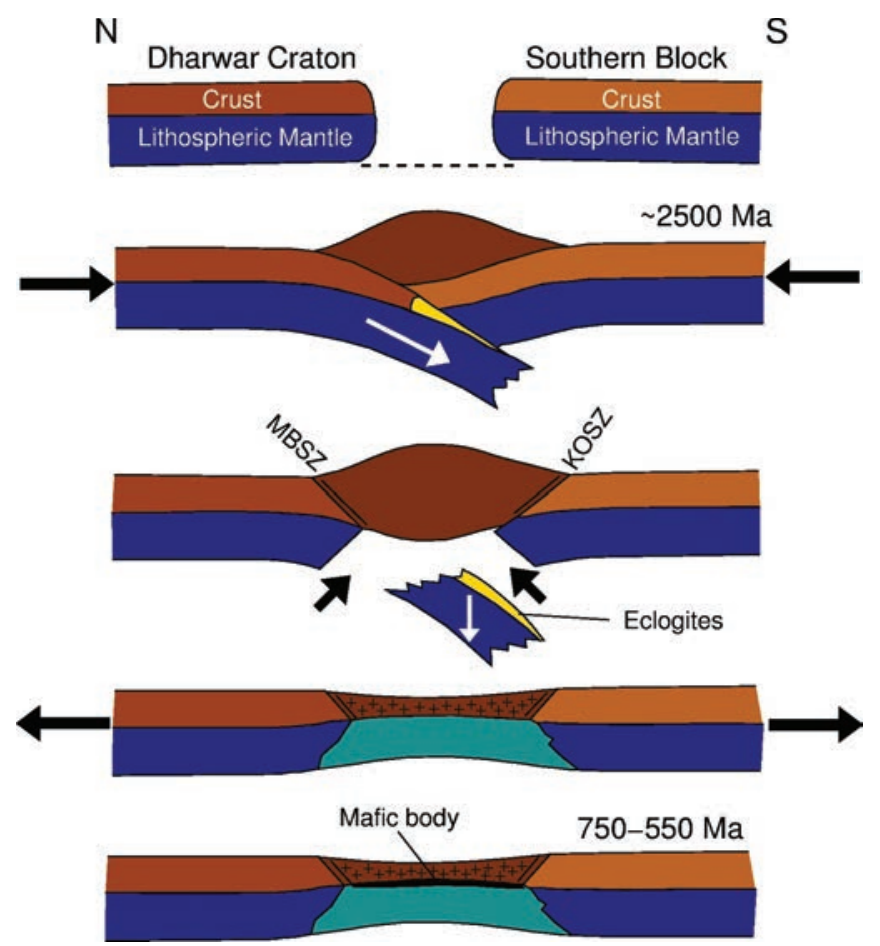

Figure 7. Schematic model showing different stages for evolution of crust in the Cauvery shear zone system (after Vijaya Rao and Rajendra Prasad, 2006). with two alternate low velocity layers of velocity $7.2 \mathrm{kms}^{-1}$, separated by a $6 \mathrm{~km}$ thick layer of velocity $8.1 \mathrm{kms}^{-1}$ (Murty et al. 2005).

Presence of granulites within the exposed gneiss of central India indicates that the upper crustal body is a pre-Archaean granulites/ amphibolites enclave in the Archaean crust. It was subjected to a large displacement during the Proterozoic tectonic activity when the Archaean crust, bounded by the faults, got uplifted. Since the end of the Precambrian until about $300 \mathrm{Ma}$ (the beginning of the Gondwana

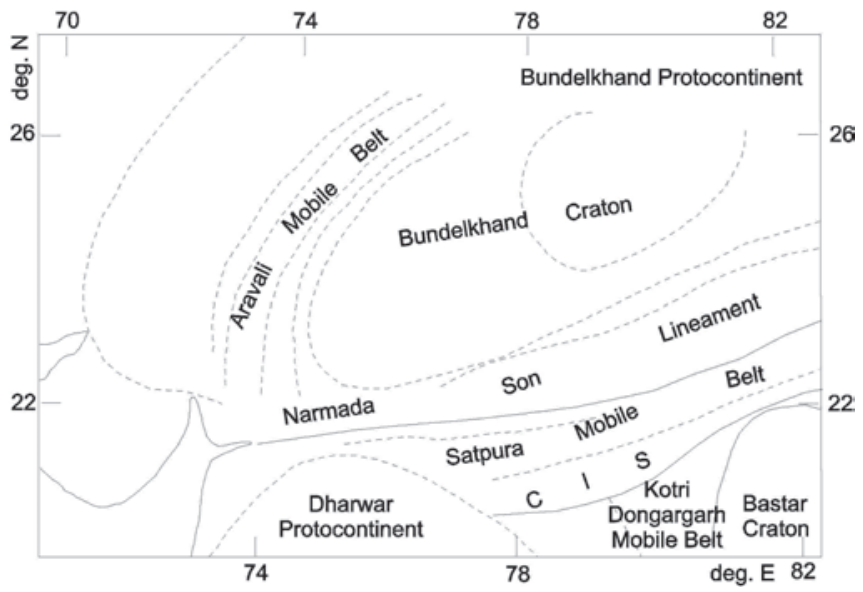

Figure 8. Tectonic framework of central India (after Kumar, 2002). CIS - central Indian suture.

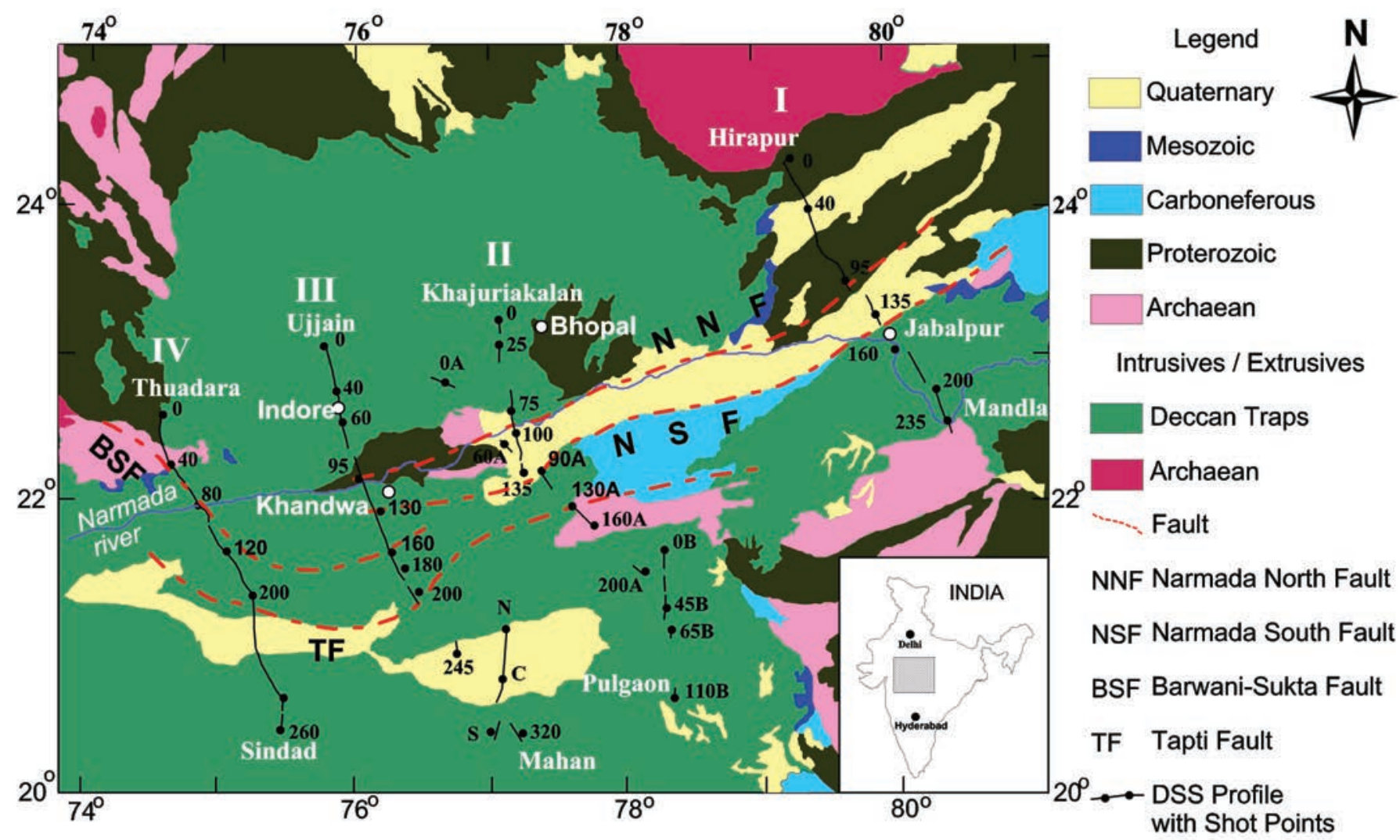

\section{km 50}

Figure 9. Seismic profiles recorded across the Narmada zone in Central India (after Kumar, 2002). NNF- Narmada north fault, NSFNarmada south fault, BSF- Barwani-Sukta fault, TF- Tapti fault. The profiles are I: Hirapur-Mandla, II: Khajuriakalan - Pulgaon, III: Ujjain - Mahan and IV: Thuuadara - Sindad. 
sedimentation) the region has remained tectonically inactive, when tectonic activity restarted. The only known major tectonic activity after this period is the Deccan Trap volcanism, which might have resulted in reactivation of the fault system. The Barwani-Sukta fault seems to have controlled the supracrustal engulfment of the granulite/ amphibolite bodies within the upper crust as the high-velocity/highdensity upper crustal layer is absent to its west (Kumar et al., 2019). This indicates that this fault may be of Proterozoic age. Presence of the underplated layer in the lower crust is another consequence of the Deccan Trap volcanism.

The central Indian suture (CIS), which is the boundary between the Satpura mobile belt to the north and Kotri-Dongargarh mobile belt to the south is another important geologic feature in central India (Figure 10). This mega-shear zone extends to a few hundred kilometers across the region and has been identified as a major Palaeoproterozoic ductile shear zone that separates two distinct tectono-magmatic terranes, the Bundelkhand protocontinent in the north and the Dharwar-protocontinent (Dharwar and Bastar cratons together) in the south (Yedekar et al., 1990). The two-pyroxene granulites that occurr in a narrow tectonic slice along southern margin of the former craton are inferred to be the metamorphic equivalents of oceanic basalt. To the south of the suture three volcano-sedimentary successions are seen. These are, the Nandgaon group, the Khairagarh group and the Dongargarh granitoid (Figure 10).

Two adjacent seismic domains, dipping towards each other are seen in the seismic reflection data. This represents a suture between the two crustal blocks. Due to the disturbed reflections from of the crust in a 20 to $30 \mathrm{~km}$-wide zone the suture itself has not imaged as a sharp boundary, which indicates that it probably has a near vertical orientation. The main features of the crust close to the suture are: oppositely dipping reflections, a Moho offset and a positive-negative gravity anomaly. These features when combined with the geological anomaly indicate that the suture is a collision zone (Figure 11) developed due to the interaction of the Bastar and Bundelkhand cratons (Mall et al. 2008; Mandal et al., 2013a). In the north-western part of the profile (65 km), a predominantly northwest dipping strong bands of reflectors that covers the entire crustal column creates a dome type structure with the apex at about $30 \mathrm{~km}$ northwest of the suture. The Moho, identified as the deepest set of reflections, varies in depth between 41 and $46 \mathrm{~km}$. It is imaged only in a few parts of the profile.

\section{North West Indian Shield}

Active tectonics was responsible for the evolution of west coast of India. This region is marked by the convergence of three major Precambrian orogenic trends (Figure 12). These are: the northnorthwest to south-southeast Dharwar in the southern part, the northeast-southwest Aravalli-Delhi in the northeastern part and east-northeast to west-southwest Satpura in the central part (Biswas, 1987). The north-northwest extension of the Dharwar trend is represented by the Cambay rift, which is the only rift graben in the western part of India. The Aravalli-
Delhi trend divides itself into three branches - the Delhi trend takes a westward swing to overlap with the Kutch Rift and the Aravalli trend crosses the Cambay rift to enter the Saurashtra plateau. The Aravalli folding takes an acute eastward swing to merge with the Satpura trend on its southern side. Development of the structural trends, rift basins and different kinds of igneous intrusions over the west coast of India and adjoining regions, after the break-up of the Gondwanaland, were also affected by the major tectonic events during the Mesozoic period.

\section{Aravalli-Delhi Fold Belt}

The most important geologic terrane in this part of the Indian shield is the Aravalli-Delhi fold belt. To the southwest of this fold

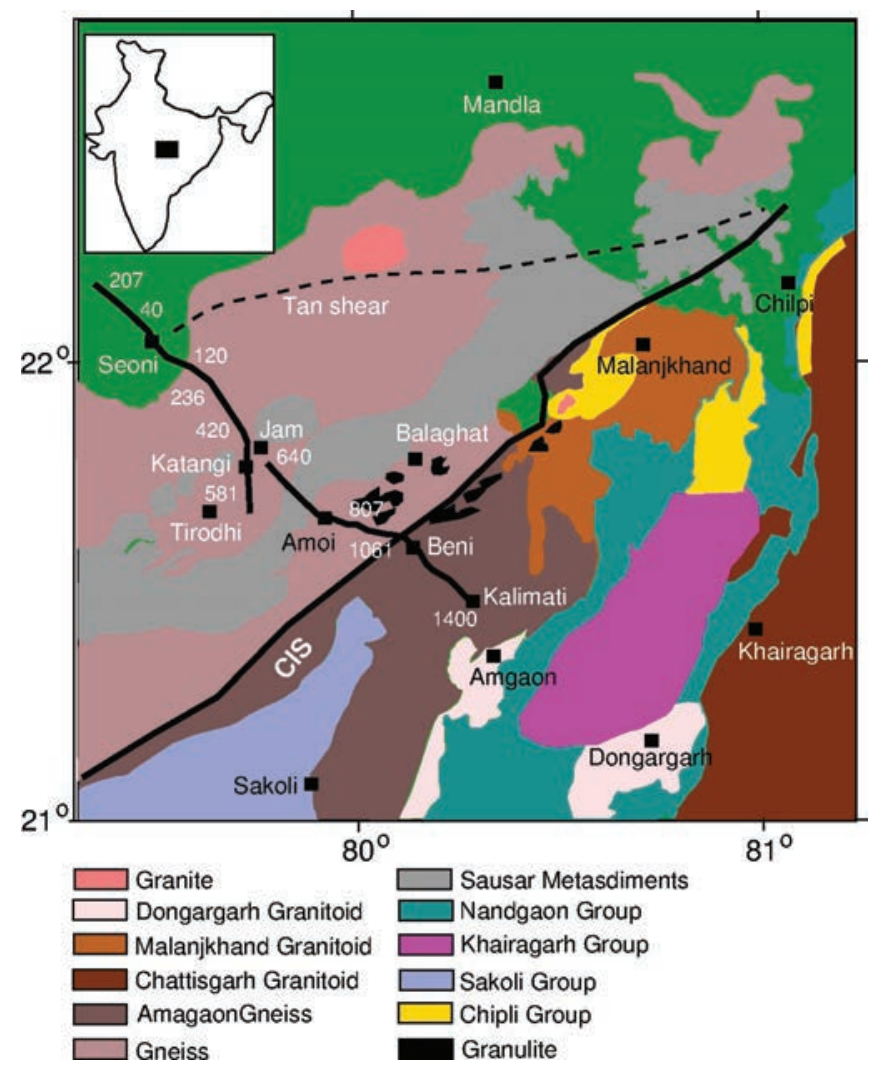

Figure 10. Location map of the deep reflection profile across the central Indian suture zone in central India (after Reddy et al., 1995). 


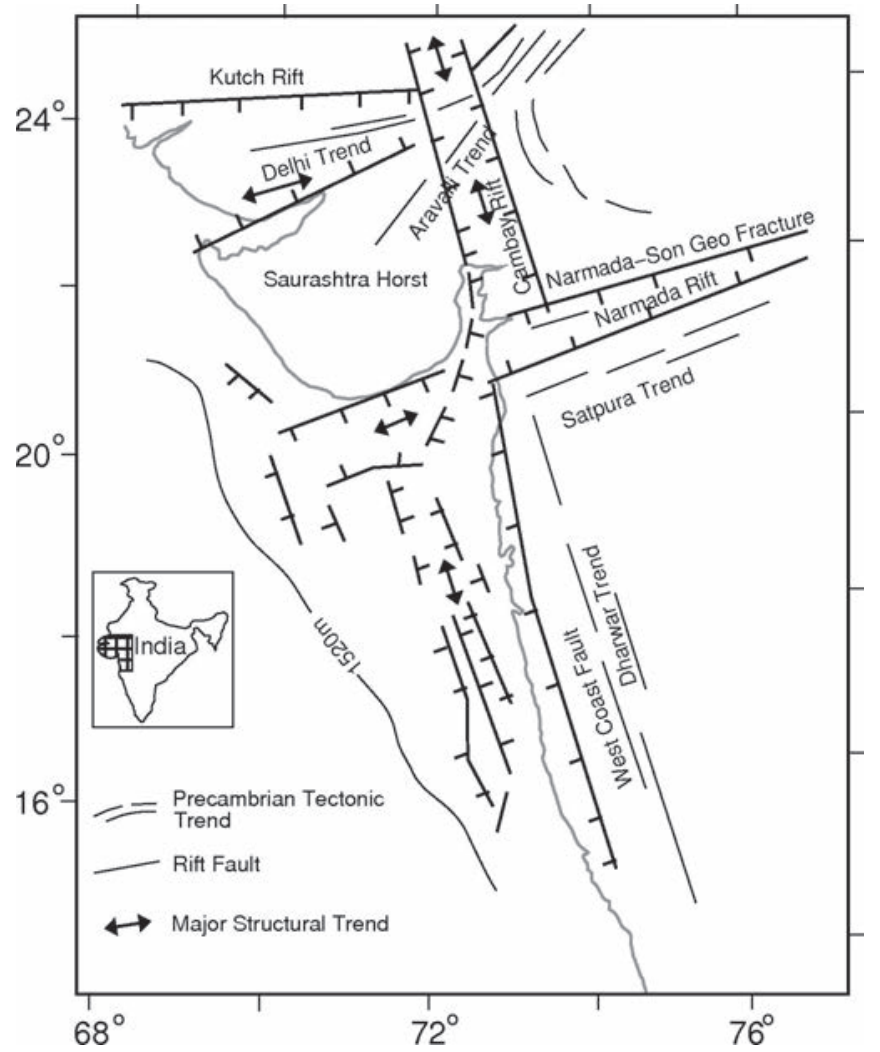

Figure 12. Major Precambrian trends in western India (after Biswas, 1987).

belt lies the Cambay basin and to its west the trans-Aravalli belt (Marwar basin). Archean to Neoproterozoic rocks are part of this fold belt (Figure 13). Development of successive Proterozoic orogenic belts on an ensialic basement of the Archean age led to growth of its crust. Four major regional tectono-magmatic and metamorphic events with ages of $\sim 3000$ Ma (Bhilwara gneissic complex), $\sim 1800 \mathrm{Ma}$ (Aravalli orogeny), $1100 \mathrm{Ma}$ (Delhi orogeny), and 850-750 Ma (post-Delhi magmatic event) have taken place in this region. The basement of most of the Proterozoic rocks present in the region is the Bhilwara gneissic complex. Reworking of this complex has taken place at about 3000 Ma. Sandmata and Mangalwar complexes and Hindoli group of rocks are major constituents of the Bhilwara gneissic complex (Sinha-Roy et al., 1995). Granulite facies rocks, which occur as isolated bodies, are part of the Sandmata complex. This complex is in thrust contact with the Delhi fold belt towards its west. The Mangalwar complex is an older granite-greenstone belt containing metavolcanic and metasedimentary rocks. Some workers consider this complex as Archaean but others think it as equivalent to Palaeoproterozoic. The Hindoli group, sandwiched between the Mangalwar complex and the Vindhyan basin, is a younger granite greenstone belt lying in the eastern part of the Bhilwara gneissic complex. The Mangalwar complex and the Hindoli group have developed together as an aulacogen and the rocks of these belts are contemporaneous with those of the Aravalli fold belt (Sinha-Roy et al., 1995)..

The Mesoproterozoic Delhi fold belt consists of over $10 \mathrm{~km}$ thick volcano-sedimentary sequences and comprises a system of half graben and horst (Sinha-Roy, 1999). To the southeast of Aravalli-Delhi fold belt lies the Vindhyan basin, one of the largest Proterozoic basins in India. The Aravalli-Delhi fold belt in the northwest and Satpura orogenic belt in the southeast constitute the margins of this basin. To west of the Delhi fold belt lies the Marwar basin. This basin consists of flat, undeformed clay evaporate sequences over the basement of granites (850 Ma) and an igneous suite of $740 \mathrm{Ma}$.

The crustal reflectivity pattern down to $18 \mathrm{~s}$ TWT, about $55 \mathrm{~km}$ depth, across the Aravalli-Delhi fold belt shows a lot of variation. The complex pattern is exemplified by generally poorly reflective upper crust and considerable variation in the lower crustal reflectivity. Deformation of the older crust is indicated by dipping reflections and the younger undeformed crust is indicated by horizontal reflections. Boundaries between different crustal units are indicated by changes in the dip direction and steeply dipping reflections, cutting across the nearly horizontal reflections at various depths in the crust. The differences in the reflectivity pattern in the crust shows that it can be divided into five blocks: a) the Marwar basin that is moderate to highly reflective, b) the Delhi fold belt that is moderate to poorly reflective, c) the Sandmata complex that is poorly reflective, d) the Mangalwar complex and Hindoli group that is highly reflective, and e) the Vindhyan basin that is moderately reflective (Tewari et al., 1997). The dips of various reflections (Mandal et al., 2013b) and the reflectivity pattern show that in this region the major shear/ dislocation zones have evolved during various phases of geotectonic activity.

Many evolutionary models have been suggested for the region of Aravalli-Delhi fold belts based on the results of several data sets (seismic, gravity, magnetic, geoelectrical, geological and geochronological) (Tewari et al., 1998; Tewari et al., 2000; Vijaya Rao et al., 2000, Tewari and Vijaya Rao, 2003; Tewari et al., 2018). Vijaya Rao et al. (2000) present a plate tectonic model that assumes development of a thermal plume under this region during the Palaeoproterozoic. This led to rifting of the continental crust, opening

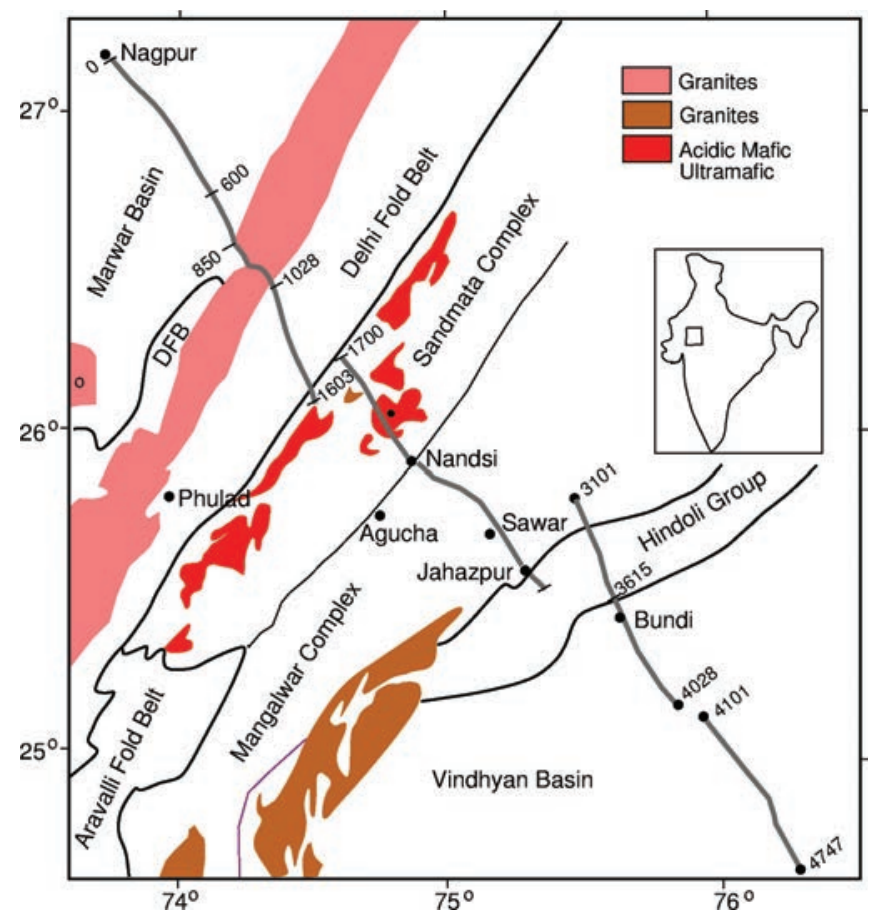

Figure 13. Geological map of the Aravalli-Delhi fold belt with the deep seismic reflection profile plotted on it (afterRajendra Prasad et al., 1998) NP-Neoproterozoic, MP-Mesoproterozoic, PPPalaeoproterozoic, MA-Middle Archaean, LA-Late Archaean. 
of an ocean and generation of a triple junction (Figuer 14). Northern and southern blocks were created within the Bhilwara gneissic complex and at around 2000 Ma the Aravalli and Hindoli sediments were deposited on the marginal basins of the Mewar and Bundelkhand cratons respectively. The eastern Bundelkhand craton (crustal block to east of the Bhilwara gneissic complex) and the western Mangalwar complex were separated by an ocean. During the Proterozoic, the compressional forces moved the eastern craton to the west. The intervening oceanic crust, along with the sediments, was subducted under the western craton due to this movement. Further convergence created an imbricated fault zone (Jahazpur thrust). Collision between the Bundelkhand craton to the east and the Marwar craton to the west, in the next stage of convergence, resulted in the Aravalli orogeny. This ultimately resulted in shortening and thickening of the crust. As the collision continued, the initial thrust became steeper and the colliding blocks got effectively locked leading to development of the Aravalli suture between the two cratons.

This environment generated the Sandmata granulites, which were thrusted up due to collision and are emplaced as tectonic wedges within the basement gneisses. Another episode of rifting took place during the Mesoproterozoic Subsequent to evolution of the Palaeoproterozoic Aravalli orogeny. This resulted in separation of the Bhilwara gneissic complex as a rift fragment from the Marwar craton and also opened an ocean. The craton consisting the Bundelkhand-Aravalli-Bhilwara gneissic terrain was to the east of this ocean and the Marwar terrain to the west. The Delhi sediments were deposited in this basin. Eastward subduction of the western Marwar craton along with the oceanic crust of the Delhi fold belt took place during the compressional phase that followed the rifting. An island arc developed due to continuous subduction of the western

NW

SE
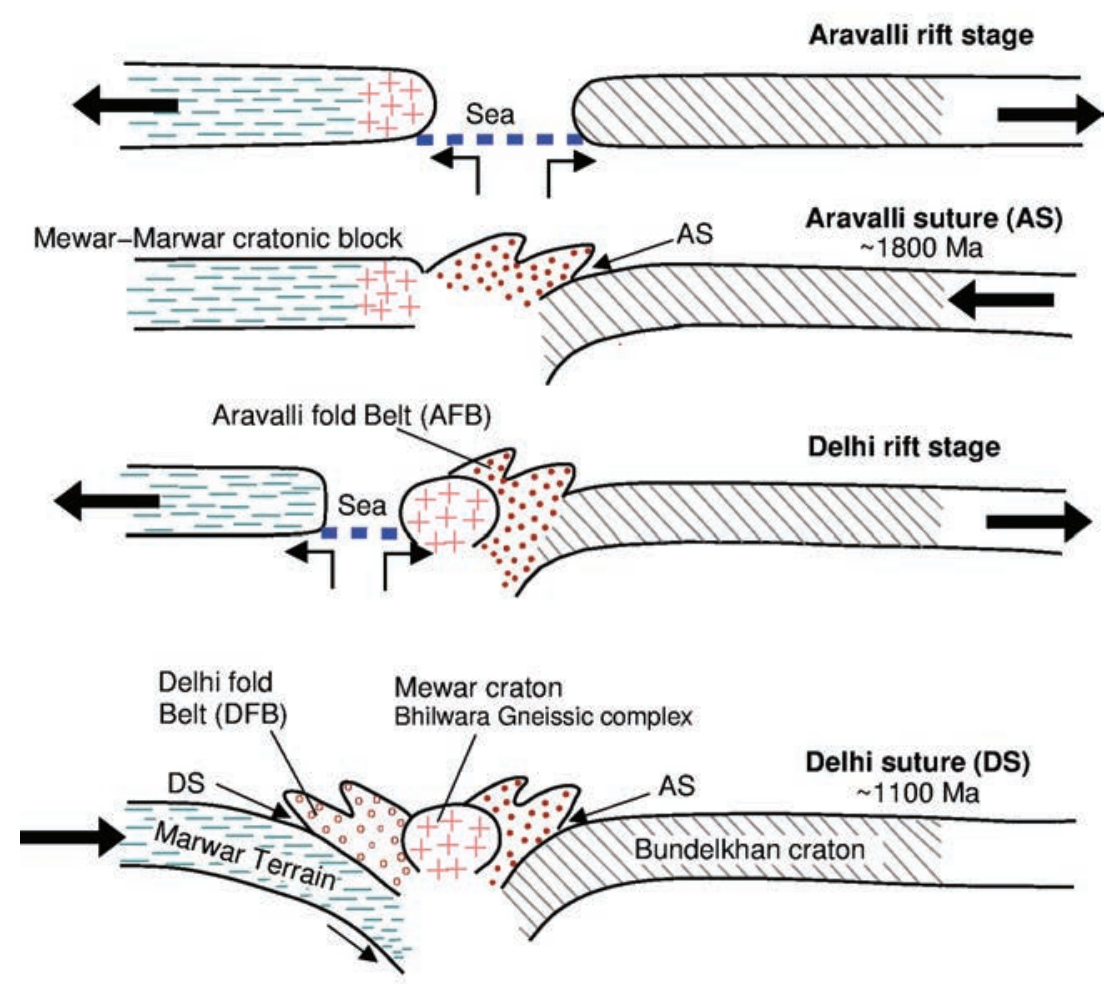

Figure 14. Cartoon showing the Evolutionary model of the Aravalli-Delhi fold belt (Vijaya Rao et al., 2000). block (Marwar). With the island arc between the Marwar and Bundelkhand-Aravalli-Bhilwara gneissic complex cratons, further convergence resulted in collision and development of the Delhi fold belt around $1100 \mathrm{Ma}$.

\section{Cambay and Saurasthra Basins}

Northward extension of the Dharwar trend of the Aravalli-Delhi fold belt, which runs parallel to the Indian west coast into the Indian shield, was responsible for origin of the Cambay basin (Figure 12). It is an intracratonic rift or graben between the Aravalli hills comprising the igneous and metamorphic rocks of Precambrian age in the northeast and Saurashtra horst, consisting of the Deccan Trap volcanics, in the west. Its eastern and western margins are bounded by step faults. During the early Cretaceous, an up welling thermal body (Reunion plume) is believed to be present in vicinity of the Cambay basin implying that at that time ideal conditions existed for magmatic extrusion in this region (Duncan and Pyle, 1988). Due to short duration of the volcanic extrusion, withdrawal of the magma from the axis in neighbourhood of the Reunion plume head was very rapid. This deflated the plume, subsequently loading the then existing surface of the Cambay basin by the volcanics and its further subsidence. Presence of up to $4000 \mathrm{~m}$ thick Tertiary sediments that were deposited in various phases of the basin development indicates large post-volcanic subsidence of this rift basin (Tewari et al., 1995).

Main crustal features of the Cambay basin are: the upper crustal low velocity zone, higher than normal velocity in the lower crust and a crust thinner than that in the Indian shield region. The thermal anomaly of the Reunion plume is also associated to presence of the free fluids either due to metamorphism at lower crustal depths or partial melting at upper crustal depths, has also led to presence of the upper crustal low velocity zone (Raval, 1989). Underplating by the upper mantle magma that was generated during passage of the Indian plate over the Reunion plume, after its break up from the Gondwanaland is responsible for higher than normal velocity in the lowermost part of the crust (Kaila et al., 1990). Thinning of the crust in the basin was caused by its proximity to the axis of the plume and tension produced due to it. Relatively thinner crust and large thickness of the Tertiary sediments indicate several stages of mantle upwarp and basin subsidence from the late Cretaceous to the Recent time (Dixit et al., 2010).

The crust in eastern Saurashtra, the Cambay basin and even in the region of the Vindhyan exposure to the immediate east of the Aravalli formation is 32-35 $\mathrm{km}$ thick as compared to $37-40 \mathrm{~km}$ beyond the eastern margin fault of the Cambay basin. It shows that the crust is uplifted by as much as 4 to $6 \mathrm{~km}$ in the eastern part of Saurashtra and Cambay basin, between the two trends of the Aravalli system (one that crosses the Cambay basin and Saurashtra and the other that turns to the east and merges with the Satpura trend) and the Narmada Fault running to the south of the Saurashtra peninsula. Since the region was close to the axis of the Reunion plume when the Indian plate moved over it during the late Cretaceous, this uplift was either concomitant with the rise of plume prior 
to the extrusion of the Deccan volcanic or after deposition of the Mesozoic sediments. Uplift of the crust in large parts of western India, eastern part of Saurashtra peninsula and the Cambay basin was also caused due to passage of the western part of India over the Reunion plume. Large dimension, 1000-2000 km, of the head of the Reunion plume (White and McKenzie, 1989) led to underplating in parts of the crust in western India. Further rise of the plume through the lithosphere caused rapid eruption of the Deccan Trap volcanic.

\section{Lithospheric thickness}

\section{Indian Shield}

Amongst the various Gondwana fragments, the Indian plate assumes a unique place as it has been ravaged by three major plumes as soon as it separated $\sim 180$ My ago from the Super-continent Gondwanaland comprising Australia, Africa, Antarctica and south America. During this process, the Indian tectonic plate lost most of its lithospheric mass and became thin vis-a-vis its counterparts. Kumar et al (2007; 2013) using state-of-the-art technique termed as S-to-p converted waves, suggested that the thickness of the Indian plate varies between $\sim 70$ and $\sim 140 \mathrm{~km}$ vis-à-vis the other fragments such as Australia, Antarctica and Africa where the thickness of lithosphere reported to be more than $150 \mathrm{~km}$. They further argued that the rapid northward drifting ( $18-20 \mathrm{~cm} / \mathrm{yr}$ ) of the Indian plate could be due to its being thin (Figure 15). Then it collided with the Asian plate at $~ 55$ Ma (Patriat and Achache, 1984; Besse et al., 1984) giving birth to the world's highest mountain chain, the Himalaya and the highest plateau, Tibet. The rapidly northward drifting ( $18-20 \mathrm{~cm} / \mathrm{yr})$ Indian plate was

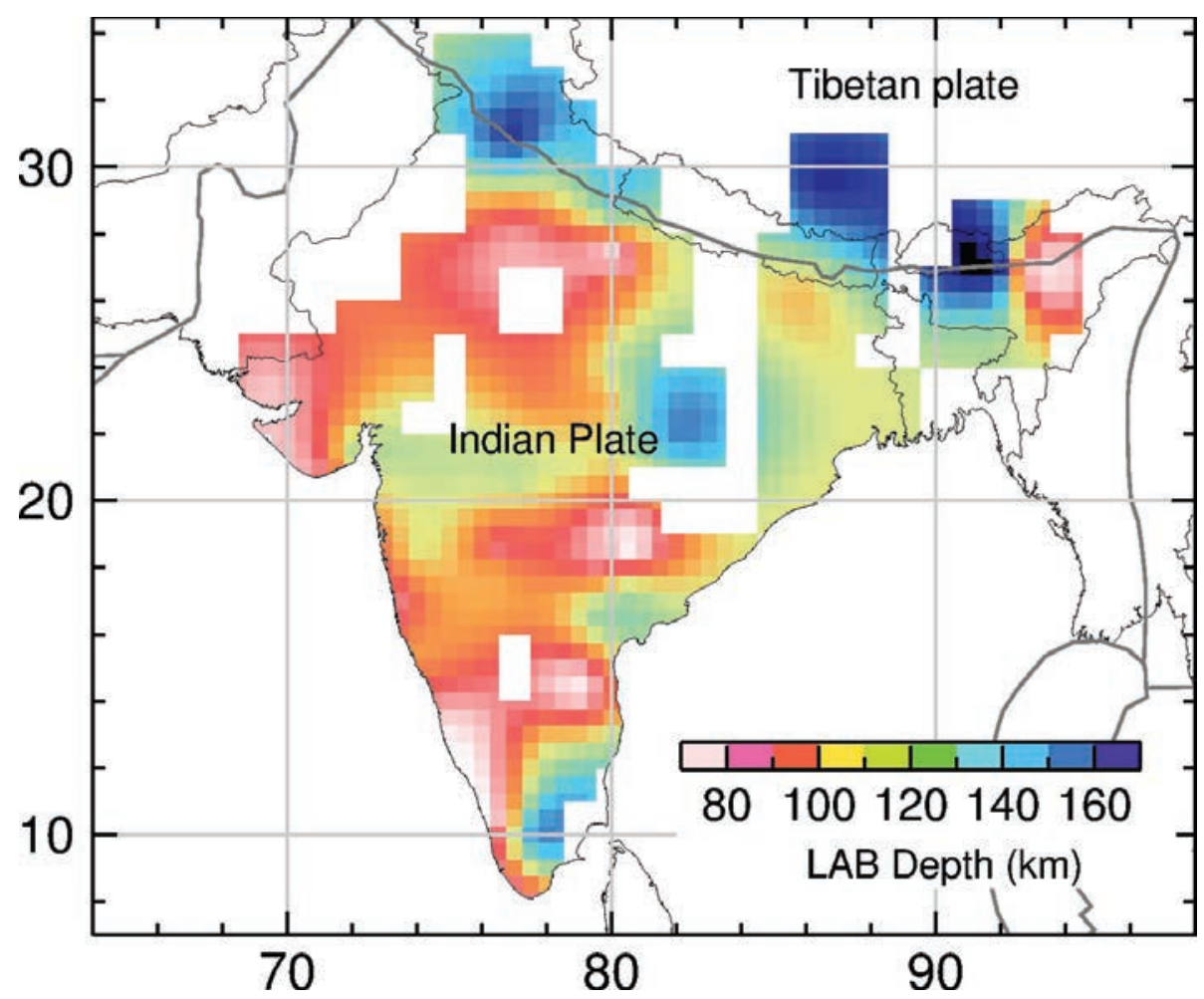

Figure 15. Image of the LAB beneath India inferred by S-receiver function data. The image has been constructed where we have sufficient number of data. The image clearly reveals the undulating LAB topography related to the flexure of the Indian plate (modified after Kumar et al., 2013). slowed down to $\sim 5 \mathrm{~cm} / \mathrm{yr}$ after the collision. A number of investigations have been made to deciphering the structure, geometry and deformation of the Himalayan collision zone and its causative mechanisms. However, the impact of continental collision, along a plate boundary spanning $\sim 2500 \mathrm{~km}$ on the Indian lithosphere away from the collision front that has an impact on the global geodynamics, remains largely unanswered.

In this context, they further observed flexure of the Indian tectonic plate caused due to the hard collision with the Asian plate along the Himalayan arc (Kumar et al., 2013) as also observed by geodetic observations. The geoid and gravity observations are explained as post-collision flexure (Bilham et al., 2003; Tiwari et al., 2013) of the Indian plate. Such flexural deformation has been observed for oceanic plates (e.g. Watts et al., 1980; Kirby, 1983) and its manifestations have been observed in gravity, geoid and bathymetry data. The primary caused for the flexure of lithosphere is surface loading or unloading. However, continents have a complex geological history and direct mapping of such flexural features is challenging since weathering annihilates the associated morphology. The receiver function analysis has further been supplemented by the analysis of the vertical components of observed seismograms without using deconvolution (i.e. plain summation (Kumar et al., 2010) consisting of back scattered reflected phases. These values are consistent with the depths observed by the analysis of surface waves (Suresh et al., 2008; Bhattacharya et al., 2009), where the lithospheric thickness has been reported to be $\sim 80$ - $155 \mathrm{~km}$. The earlier tomographic image also shows that among the various depth extents of the cratons, India is only $100 \mathrm{~km}$ (Polet and Anderson, 1995). A GEOSCOPE station located at Hyderabad (HYB) shows a similar depth value for the lithosphere below the Indian shield using P-to-s conversions (Rychert and Shearer, 2009; Bodin, et al., 2014). The tomographic images by Maurya et al (2016) showed quite distinct lithospheric thickness for the entire Indian shield. However, their values in southern granulitic terrain, eastern Dharwar are in agreement with the other observations, but for other cratons there exist significant differences with their values between 160 and $200 \mathrm{~km}$.

Due to the loss of most of its lithospheric mass, the Indian plate buckled, followed by erosion. Geothermobarometry studies indicate that the maximum pressure and temperature reported in the southern part of Indian continent are upto $\sim 8 \pm 1.5 \mathrm{~kb}$ and $775 \pm 30^{\circ} \mathrm{C}$ (Rao et al., 1991) respectively. Such value suggest the exhumation of intermediate to lower parts of the crust. The geotectonic history, geochemistry and geophysical signatures all along the Indian plate are quite different. Further, the sutures and lineaments have repeatedly been rejuvenated over the course of geological time (Rogers and Callahan, 1987; Naqvi and Rogers, 1987). Also, the vast extent of the basalt volcanism in the central and western Indian regions are also manifested in the crustal structure in terms of underplating above the Moho as revealed by the seismic 
reflection/refraction studies (e.g. Kaila and Krishna, 1992; Tewari et al., 2000; Tewari and Kumar, 2003; Tewari et al., 2001). All these factors might have perhaps made the Indian lithosphere, especially the crustal part, more heterogeneous.

A $100 \mathrm{~km}$ thick Indian shield lithosphere (Kumar et al. 2007) seems to gradually thickens as it reaches the Himalaya where the Indian Plate undergoes homogenous thickening. An abrupt increase in the plate thickness is seen at the northern end of the foredeep region where the depth to LAB reaches $\sim 140 \mathrm{~km}$. Estimates of lithospheric thickness values in Tibet derived from application of the $S$ receiver function technique to the INDEPTH data (Kumar et al. 2006), reveal existence of strong distinct lithospheres in the northern as well as southern Tibet with the India lithosphere subducting below the Asian lithosphere just south of Bangong suture zone.

\section{North-Eastern part of Indian plate}

Further, significant work has been done with imaging of the detail lithospheric architecture of the subducting slab using S-to-p receiver functions up to a depth of $200 \mathrm{~km}$ (Figure 16) (Uma et al., 2011). The interesting observations of the lithospheric upwelling below the Shillong plateau suggest that the uplift of the plateau is confined to the lithospheric level. Also, the Indian lithosphere is imaged to be under thrusting along the Burmese arc.

The Shillong plateau wedged between the Himalayan collision in the North and the Burmese subduction in the East is an enigmatic geodynamic feature of the Indian Plate, in view of its elevation

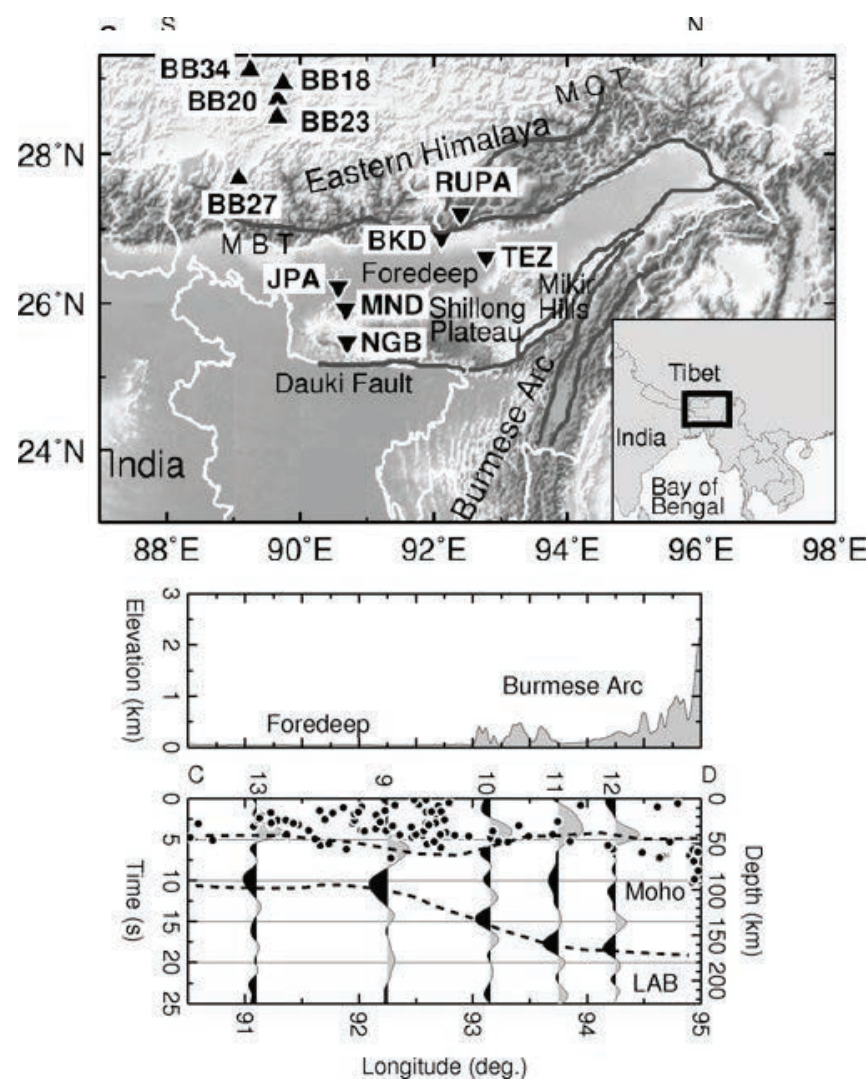

Figure 16. The stacked traces plotted together with elevation along geographic East-West profile. The black dots are the local seismicity within a narrow width along the profile. The first positive peak is Moho followed by the second negative phase (from the lithosphereasthenosphere boundary. (average $1 \mathrm{~km}$ ). The evidence for the plateau uplift has been suggested by the results of geodetic levelling by the Geodetic and Research Branch of the Survey of India, (Kailasam 1979). Chen and Molnar (1990) suggest that a cold upper mantle based on the studies of the occurrence of earthquakes at subcrustal depths (focal depths $>40 \mathrm{~km}$ ) beneath the plateau. Therefore, it implies that the uplift of the Shillong plateau could not have been caused by the thermal source due to an earlier hotspot or plume activity. An interesting model for the upliftment have been proposed by Rao and Kumar (1997) based on the analysis of focal mechanisms and computation of strain rates. It is suggested that the Shillong plateau was up- lifted under the influence of compressive stresses resulting from the India-Eurasia collision in the North, aided by a timely impetus from the India-Burma thrust forces in the east, which is sustained even at present. In such scenario, a thin lithosphere in the vicinity of the plateau could mean that the uplift represents a lithospheric up warp related to flexure and not a crustal one, because the crustal thickness is only $35 \mathrm{~km}$.

\section{Himalayan Arc}

It has been established that the Tibetan plateau was created by the collision of the northward moving Indian plate with the relatively stationary Asian plate. The collision began about 50 million yr ago. However, all along the collision arc, the mode of deformation of the mantle lithospheres remained largely unknown. A fundamental question is whether the post-collision convergence of India and Asia, estimated at >2000 km (Houseman et al., 1981; Molnar et al., 1993), was accommodated by homogeneous thickening or plate subduction. Modelling indicates that the Tibetan part of the lithosphere originated from the progressive accretion of a number of continental or islandarc type blocks before India came into direct contact with Asia (Allegre et al., 1984) or stepwise subduction of the Asian plate (Tapponnier et al., 2001). A large number of broadband passive source seismic experiments by different rearch groups have been conducted in the Tibetan plateau over the last $20 \mathrm{yr}$. Most of them are located in southern central and eastern Tibet. P- and S- receiver functions from the seismic records have been computed by various researchers.

The final interpretative models all along the Himalayan arc has been prepared after synthetizing all the available results from receiver functions (e.g. Kind et al., 2002; Kumar et al., 2005; Kumar et al., 2006; Zhao et al., 2010; Zhao et al., 2011). The left most interpretative model along Tien-Shan Karakoram profile (Figure 17), shows that the Asian plate seems to be dipping under the Indian plate. The depth extent of the Asian plate is marked till $\sim 300 \mathrm{~km}$ corroborative with the local seismicity and surface wave tomographic findings (Friederich, 2003). Figure 17 matches with the sketches by Willett and Beaumont (1994) who discuss possible models of the collision of the two lithospheric plates. The crust is marked yellow in all profiles without any details or separation between the different plates.

In northern and eastern Tibet (west line and east line) lines are shown in Figure 16, where the Indian plate under thrust the Tibetan and Asian plates along the arc. Here all lithospheric thicknesses are obtained with $\mathrm{S}$ receiver functions. The lithospheric geometry of the Indian and Asian plates is well-imaged by several profiles and suggests a changing mode of India-Asia collision in the east-west direction. From eastern Himalayan syntaxis to the western edge of the Tarim Basin, the Indian lithosphere is under- thrusting Tibet at an increasingly shallower angle and reaching progressively further to the north. 


\section{Andaman-Nicobar Islands}

Oceanic plates are created at mid-oceanic ridges and consumed along the trenches by subduction (Figure 18). Along the trenches, the oceanic plates are in continuous motion. Seismological studies in the Indian Ocean region started pace after the occurrence of a large earthquake on $26^{\text {th }}$ Dec, 2004 of Mw 9-9.3 and therefore caused a major Tsunami in the Indian Ocean. The region has a complex tectonic setting and plays an important role in shaping the geodynamics of the oceanic plate (Mishra et al., 2007a, and b). Khan (2011) studied the unbalance of the subducting slab based on the moment calculation. Quite a number of studies have been conducted to understand the fault disposition, rifting mechanism and subduction tectonics based on the seismicity disposition. A detail crustal and lithospheric structures have been imaged (Kumar et al., 2016) using S-to-p receiver function studies, where the down-going of the Indian oceanic plate below the Andaman arc suffers deformation and lithospheric tearing possibly due to the dehydration of the slab (Mishra et al., 2007a). Such an intriguing feature of slab tear has never been imaged earlier using high resolution seismic waves. Such studies are done in Pacific and Philippine Sea plates based on the exclusive bore-hole broadband ocean bottom seismological observatory data for the first time by Kawakatsu et al (2009) and (Kumar and Kawakatsu, 2011; Kumar et al., 2011). They further reported the nature of pure oceanic plates.

In the Andaman-Nicobar region, a seismological experiment has been designed to image the nature and geometry of the subducting Indian plate beneath the Andaman-Nicobar Island arc (as shown in Figure 18) by installing broadband seismic instruments. In the aftermath of the mega 2004-Sumatra earthquake (Mw 9.3) followed

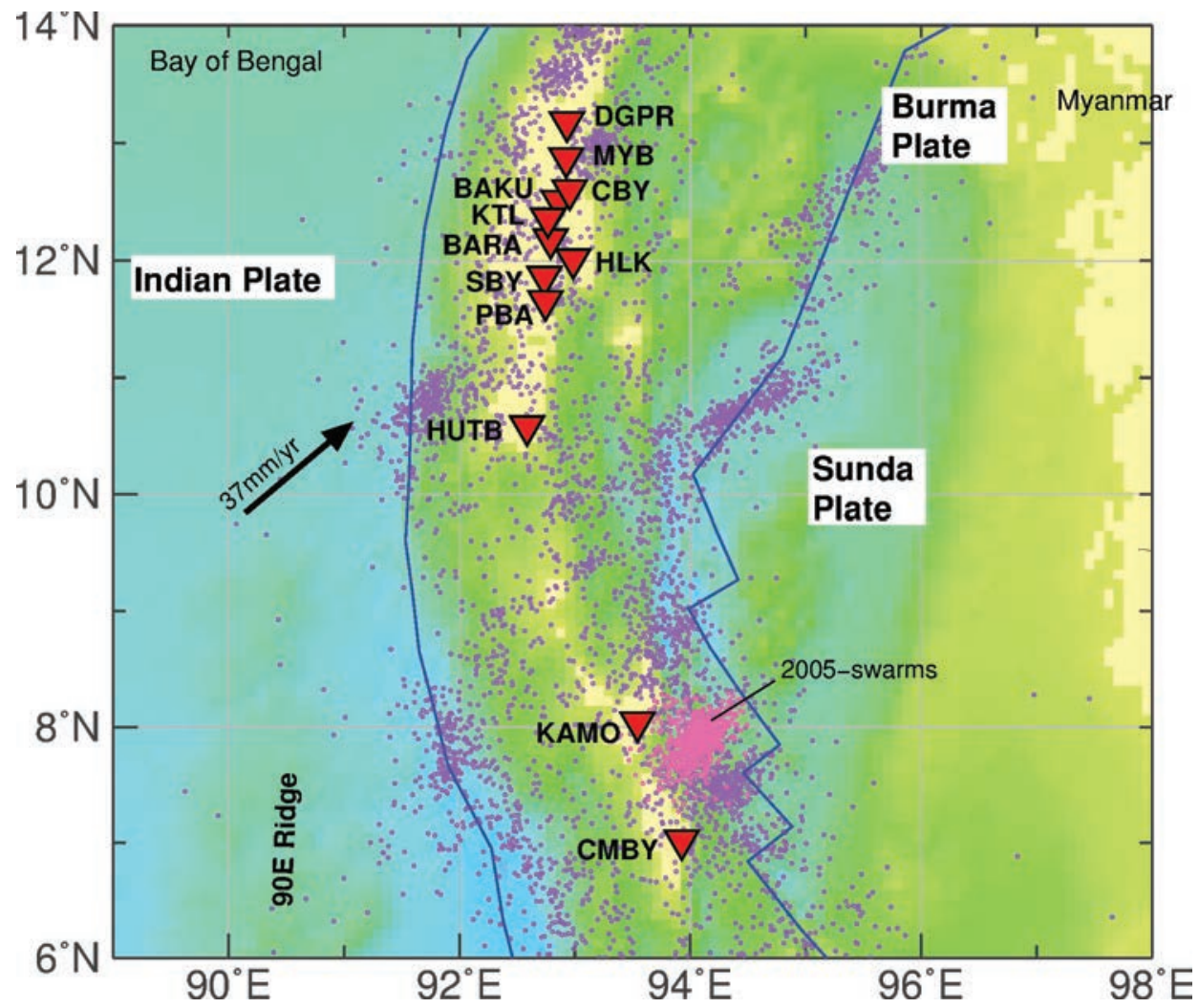

Figure 18. Topographic map with the location of stations shown in Andaman-Nocobar Islands (red). The names of the stations are indicated. The seismicity (purple dots) and the 2005 swarm (pink) are also displayed. The plate boundaries are shown by thin blue lines. seismologist world over.

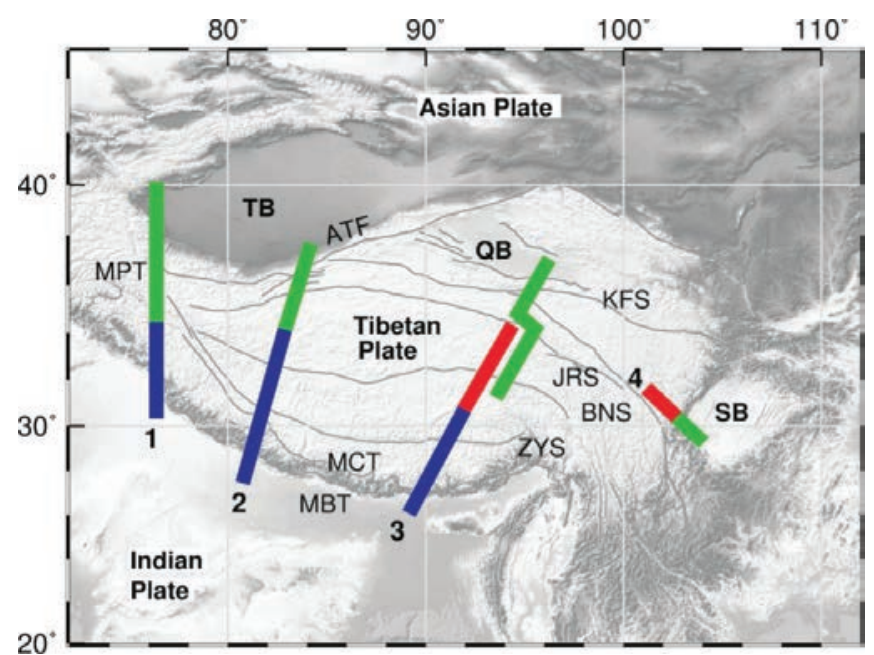

Figure 17. Map of the Tibetan plateau showing the seismic profiles. The west and central lines are our recent profiles. Main Boundary Thrust (MBT), Main Central Thrust (MCT), Yarlong-Zangbo Suture (YZS), Bangong-Nujiang Suture (BNS), Jinsha-River Suture (JRS), Altyn-Tagh Fault (ATF), and Qaidam Basin Fault (QBF). Blue and green bars with arrows mark Lithosphere observations of the Indian (IML) and Asian (AML) plates, respectively. Red bar is the Tibetan lithosphere.

by the deadly Tsunami, this region has attracted the attention of

The Andaman region is geodynamically complex and characterized by the existence of an active spreading centre in the back-arc beneath the Andaman Sea (e.g. Khan and Chakraborty, 2005), and the interaction of the linear $90 \mathrm{E}$ ridge with the trench (Figure 19). The mapping of the reason is challenging due to its strctural complexity. Seismologically, this region is one of the least studied in the world. Figure 19 displays the S-receiver function migrated images below the Andaman-Nicobar Islands down to the uppermost mantle. The image has been constructed using a large number of teleseimic three component sesimological data from the broadband stations deployed in the Andaman-Nicobar Island. The image down to 20-30 km depth, reveals that there are two oppositely dipping features i.e. one from the Indian ocean side and the other from the Andaman back arc side. It also, suggest that the thickness of the 80-90Ma old Indian ocean plate, which is subducting below the Andaman-Nicobar Island region is $\sim 50 \mathrm{~km}$. Such valus for the oceanic lithosphere is somewhat lower than that predicted by the thermal model. The reason for this discrepancy could be due the deviation from a normal oceanic mantle due to the presence of sea-mounts and ridges reported here (e.g. Raju et al., 


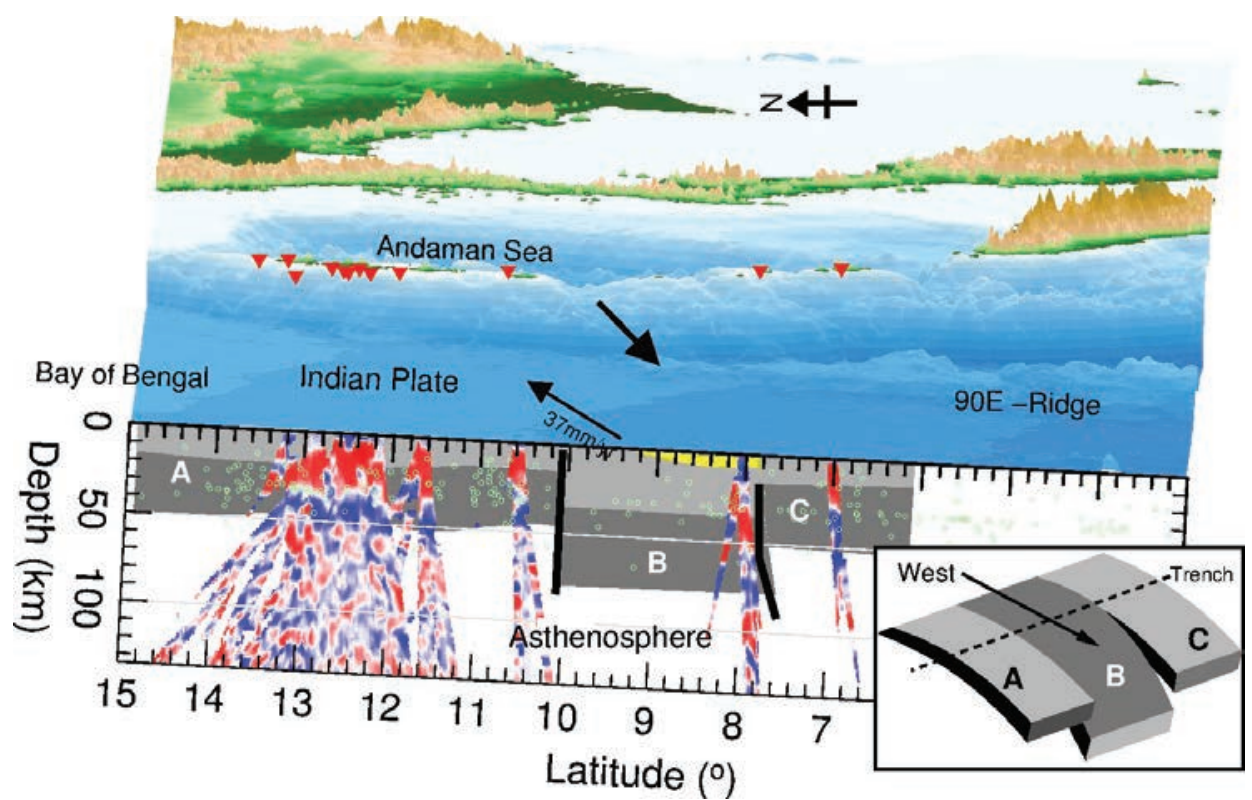

Figure 19. Receiver function image along the north-south profile parallel to the Andaman-Nicobar trench, with the station locations. The average thickness of the lithosphere (gray colour) is $\sim 50 \mathrm{~km}$ from north to south along the arc, except in the vicinity of $\sim 8$ deg latitude, where it deepens to $\sim 80 \mathrm{~km}$. The seismicity ( $\mathrm{Mb}>5$, green dots) are well within the lithosphere. This abrupt offset of the middle part of the lithosphere has been interpreted as caused by the tearing in oceanic slab (interpretive model in bottom-right inset) (Modified from Kumar et al., 2016).

shield reveals a crustal thickness in excess of $40 \mathrm{~km}$ along the entire stretch. A plausible evolutionary model suggests that due to compressional forces the Dharwar craton and the southern block came closer to each other leading to a collision during the late Archaean. The crustal roots of a thickened crust became denser than the underlying mantle lithosphere, causing delamination.

The seismic velocity-depth model of the central Indian crust is intriguing. The presence of sub-crustal laminar low velocities altered the rheology of the central Indian crust. The high velocity anomaly in the upper crustal depth suggests that the Barwani-Sukta fault has controlled the supracrustal engulfment of the granulite/amphibolite bodies within the upper crust, further hinting that the fault is of Proterozoic age.

The crustal reflectivity pattern in Aravalli region shows variations and indicating different crustal blocks. An evolutionary model has also been presented.

In Cambay basin, the interesting

2004). The presence of Ninety East Ridge might affect the plate structurally. The seismic images further reveal that there exists an offset in the subducted lithosphere relative to the adjacent down going slabs along the arc. Kumar et al (2016) interpret this offset as being caused by tearing in the oceanic lithosphere. This geodynamic feature has also been corroborated by the Seismicity and tomography studies in other places along the Burma-Andaman-Sumatra trench (e.g. Dasguta et al., 2003 etc). The lithospheric tears are important as it serves as vents for the outpouring of the asthenospheric material as indicated by the presence of numerous volcanoes in these regions (Curray, 2005). It is also seen that the lava samples from the Barren islands are having affinity towards the mantle or deep mantle origin (e.g. Alam et al., 2004).

\section{Conclusions}

Here, we present a comprehensive picture of the crustal and lithospheric structure of the Indian shield, Himalayan and Burmese arcs and Andaman-Nicobar subduction zones. The results are based on the findings of deep seismic sounding and passive seismology. The implications of the studies have also been discussed at the end of each section in terms of their geodynamics and metallogeny.

The deep seismic sounding studies indicate that the crustal thickness of the Indian shield varies from $\sim 30$ to $48 \mathrm{~km}$ in most regions except in the Himalayan region, where it goes up to $\sim 70 \mathrm{~km}$ as observed by receiver function analysis. The large variations in crustal parameters throughout the Indian shield, its evolution through a complex geological history, makes the Indian crust heterogeneous. The crust beneath Proterozoic Cuddapah basin is about $42 \mathrm{~km}$ thick, while in the Western Dharwar Craton the thickness varies between $\sim 38$ and $40 \mathrm{~km}$. The north-south DSS profile in the south Indian features are the upper crustal low velocity zone, higher than normal velocity in the lower crust and a crust thinner than that in the Indian shield region. The low velocity zone could be associated with the presence of the free fluids. The crustal thickness of Saurashtra, the Cambay basin are of the order of $32-35 \mathrm{~km}$ as against $37-40 \mathrm{~km}$ beyond the eastern margin fault of the Cambay basin.

The detailed seismological studies using the state-of-the-art tool i.e. S-to-p receiver functions, suggest the presence of negative velocity jump at a depth of $80-140 \mathrm{~km}$ beneath the Indian shield. The low velocity layer has been interpreted as the boundary between lithosphere and asthenosphere. Low value of lithospheric thickness beneath the Indian shield has been viewed as the loss of the lithospheric mass due to the hot plumes when the Indian plate passed over them. Thus, the thinner fast drifting Indian plate moved northward and collided with the Asian plate, generating the world's highest mountain chain, Himalaya and highest plateau, the Tibet. The massive collision made the flexure in the Indian plate.

Further, the lithospheric image along the Himalayan arc reveals that the mode of convergence of the Indian plate beneath the Asian plate is changing from east to west. However, in the east the Indian plate has been traced upto a depth of $200 \mathrm{~km}$, indicaing a subduction secnario. Further, the lithospheric architecture of the oceanic Indian plate has been imaged beneath the Andaman-Nicobar island arc and tearing in the Indian oceanic plate is suggested.

\section{Acknowledgements}

We are extremely grateful to Dr. V. M. Tiwari for his invitation to contribute this research article focusing on lithospheric framework on Indian peninsula. Thanks to Director, CSIR-NGRI, for his permission to publish this article. We thank Dr. V. M. Tiwari and two anonymous reviewers for their critical reviews to improve the 
manuscript. The article has reference number NGRI/Lib/2019/ Pub-47.

\section{References}

Alam, M. A., D. Chandrasekharam, O. Vaselli, B. Capaccioni, P. Manetti, and A. P. Santo (2004), Petrology of the prehistoric flows and dykethe Barren Island, Andaman Sea, Indian Ocean, in Proceedings of the Indian Academy of Sciencs (Earth and Planetary Sciences), Special Issue: Magmatism in India Through Time, vol. 113, pp. 715-721.

Allègre CJ, et al. (1984), Structure and evolution of the HimalayaTibet orogenic belt. Nature 307:17- 2 .

Besse, J., V. Courtillot, J. P. Possi, M. Westphal, and Y. Z. Zhou (1984), Paleomagnetic estimates of crustal shortening in the Himalayan thrusts and Zangbo suture, Nature, 311, 621-626.

Bhaskar Rao Y. J., Janardhan A. S., Vijay Kumar T., Narayana B. L., Dayal A.M., Taylor P. N. and Chetty T.R.K., (2003). Sm-Nd model ages and $\mathrm{Rb}-\mathrm{Sr}$ isotopic systematics of charnockite and gneisses across the Cauvery Shear Zone, southern India: implications for the Archaean-Neoproterozoic terrane boundary in Southern Granulite Terrene. In: (M. Ramakrishnan, Ed.), Tectonics of Southern Granulite Terrene, Kuppam-PalaniGeotransect. Geol. Soc. India, Mem. 50, 297-317.

Bhattacharya, S. N., G. Suresh, and S. Mitra (2009), Lithospheric Swave velocity structure of the Bastar Craton, Indian Peninsula, from surface-wave phase-velocity measurements, Bull. Seismol. Soc. Am., 99, 2502-2508.

Bilham, R., R. Bendick, and K. Wallace (2003), Flexure of the Indian Plate and intraplate earthquakes, Proc. - Indian Acad. Sci., Earth Planet. Sci., 112(3), 1-14.

Biswas S. K., (1987). Regional tectonic framework, structure and evolution of western marginal basins of India. Tectonophysics, 135, 307-327.

Bodin, T., H. Yuan, and B. Romanowicz (2014), Inversion of receiver functions without deconvolution application to the Indian craton, Geophys. J. Int., 196(2), 1025-1033, doi:10.1093/gji/ggt431.

Chen, W. P., \& Molnar, P. ( 1990), Source parameters of earthquakes and intraplate deformation beneath the Shillong Plateau and Northern Indoburman Ranges. J. Geophys. Res., 95, 12,527$12,552$.

Chetty T. R. K., Bhaskar Rao Y.J. and Narayana B. L., (2003). A structural cross section along Krishnagiri-Palani corridor, Southern Granulite Terrene of India. In: (M. Ramakrishnan, Ed.), Tectonics of Southern Granulite Terrene, KuppamPalaniGeotransect. Geol. Soc. India, Memoir, 50, 255-277.

Curray, J. R. (2005), Tectonics and history of the Anda-man Sea region, J. Asian Earth Sci.,25, 187-32.

Dasgupta, S., M. Mukhopadhyay, A. Bhattacharya, T.K. JanaThe geometry of the Burma-Andaman subducting lithosphere J. Seismol., 7 (2003), pp. 155-174.

Dasgupta, S., Mukhopadhyay, B., Acharyya, A. (2007b), Seismotectonics of the Andaman-Nicobar Region: Constraints from Aftershocks within 24 Hours of the Great 26 Dec. 2004 Earthquake, In: Sumatra-Andaman earthquake and Tsunami 26 Dec. 2004 (Ed. Sujit Dasgupta), Geol. Surv. India, Spec. Publ., v.89, pp.95-104.

Dixit M. M., Tewari H. C. and Visweswara Rao V., (2010). Twodimensional velocity model of the crust beneath south Cambay basin, India from refraction and wide-angle reflection data, Geophy. Jour. Int. 181, 635-652.

Duncan, R. A., and Pyle, D. G., (1988). Rapid eruption of Deccan flood basalts, western India, in Deccan Flood Basalts, vol., 10, pp 1-10, ed. Subbaraom K. V., Mem. Geolo. Soc. India, Bangalore. Durheim R. J. and Mooney W. D., (1994). Evolution of the Precambrian Lithosphere: geological and geochemical constraints. Jour. Geophys. Res., 99, 15359-15374.

Friederich, W. (2003), The S-velocity structure of the East Asian mantle from inversion of shear and surface waveforms, Geophys. J. Int., 153, 88 - 102.

Houseman, G. A., D. P. McKenzie, and P. Molnar (1981), Convective instability of a thickened boundary layer and its relevance for thermal evolution of continental convergent belts, J. Geophys. Res., 86, 6115 - 6132.

Kaila K. L, Roy Choudhury K., Reddy P. R., Krishna V. G., Hari Narain, Subbotin S. I., Sollogub V. B., Chekunov A. V., Kharetchko G. E., Lazarenko M. A. and Ilchenko T. V., (1979). Crustal structure along Kavali-Udipi profile in the Indian Peninsular Shield from the deep seismic soundings, Jour. Geol. Soc. India, 20, 307-333.

Kaila K. L., Tewari H. C., Krishna V. G., Dixit M. M., Sarkar D.and Reddy M. S., (1990). Deep Seismic sounding studies in the North Cambay and Sanchor basins, India, Geophys. Jour. Int., 103, 621637.

Kaila K. L., Tewari H. C., Roy Choudhury K., Rao V. K., Sridhar A. R. and Mall D. M., (1987). Crustal structure of the Northern part of the Proterozoic Cuddapah basin of India from deep seismic soundings and gravity data, Tectonophysics, 140, 1-12.

Kaila, K. L., and V. G. Krishna (1992), Deep seismic soundings studies in India and major discoveries, Special Issue: Seismology in IndiaAn Overview, Curr. Sci., 62, 117-154.

Kailasam, L.N., (1979), Plateau uplift in Peninsular India. In: T.R. McGetchin and R.B. Merrill (Editors), Plateau Uplift: Mode and Mechanism. Tectonophysics, 61: 243-269.

Kawakatsu, H., P. Kumar, Y. Takei, M. Shinohara, T. Kanazawa, E. Araki, and K. Suyehiro (2009), Seismic evidence for sharp lithosphere-asthenosphere boundaries of oceanic plates, Science, 324, 499-02, doi:10.1126/science.1169499.

Khan P.K. Chakraborty P.P. , (2005), Two-phase opening of Andaman Sea: a new seismotectonic insight, Earth Planet. Sci. Lett., 229, $259-271$.

Khan, P.K., Biswas, B., Samdarshi, P. and Prasad, R., (2011), Seismicity and the Coda-Q Variation in Eastern Indian Shield Region, Ind. Jour. Geosci., v. 65, p. 131-138.

Kind R, et al. (2002), Seismic images of crust and upper mantle beneath Tibet: Evidence for Eurasian plate subduction. Science 298(5596):1219-1221.

Kirby, S. H. (1983), Rheology of the lithosphere, Rev. Geophys. Space Phys., 21(6), 1458-1487.

Kumar P, Yuan X, Kind R, Kosarev G (2005), The lithosphereasthenosphere boundary in the Tien Shan-Karakoram region from S receiver functions: Evidence for continental subduction. Geophys Res Lett 32(7):doi: 10.1029/2004GL022291.

Kumar P, Yuan X, Kind R, Ni J (2006), Imaging the colliding Indian and Asian lithospheric plates beneath Tibet. J Geophys Res 111(B6):doi: 10.1029/2005JB003930.

Kumar, P., (2002). Seismic structure of the continental crust in the central Indian region and its tectonic implications, Thesis submitted to Osmania University, Hyderabad (unpublished).

Kumar, P., and H. Kawakatsu (2011), Imaging the seismic lithosphereasthenosphere boundary of the oceanic plate, Geochem. Geophys. Geosyst., 12, Q01006, doi:10.1029/2010GC003358.

Kumar, P., G. Srijayanthi, and M. Ravi Kumar (2016), Seismic evidence for tearing in the subducting Indian slab beneath the Andaman arc, Geophys. Res. Lett., 43, 4899-4904, doi:10.1002/ 2016 GL068590.

Kumar, P., H. Kawakatsu, M. Shinohara, T. Kanazawa, E. Araki, and 
S. Kiyoshi, P and S receiver function analysis of seafloor borehole broadband seismic data, J. Geophys. Res., 116, B12308, doi:10.1029/2011JB008506, 2011.

Kumar, P., M. Ravi Kumar, G. Srijayanthi, K. Arora, D. Srinagesh, R. K. Chadha, and M. K. Sen (2013), Imaging the lithosphereasthenosphere boundary of the Indian plate using converted wave techniques, J. Geophys. Res. Solid Earth, 118, doi:10.1002/ jgrb.50366.

Kumar, P., R. Kind, and X. Yuan (2010), Receiver function summation with out deconvolution, Geophys. J. Int., 180(3), 1223-1230, doi:10.1111/j.1365-246X.2009.04469.x.

Kumar, P., Tewari, H. C., and G. Khandekar, An Anomalous high velocity layer at a shallow crustal depth across the Narmada zone, India, Geophys. J. Int., 142, 95-107, 2000.

Kumar, P., Tewari, H. C., and Sreenivs, B., (2019) Seismic structure of the Central Indian Crust and its Implications on the Crustal Evolution, J. Geol. Soc. India, 93, 2, 163-170.

Kumar, P., X. H. Yuan, M. R. Kumar, R. Kind, X. Q. Li, and R. K. Chadha (2007), The rapid drift of the Indian tectonic plate, Nature, 449, 894-897, doi:10.1038/nature06214.

Mall D. M., Reddy P.R. and Mooney W.D., (2008). Collision tectonics of the Central Indian Suture zone as inferred from a deep seismic sounding study, Tectonophysics, 460, 116-123.

Mandal, B., Sen, M. K., Rao, V., (2013a) New seismic images of the Central Indian Suture Zone and their tectonic implications, Tectonics, 32, 4, 908-921.

Mandal, B., Sen, M. K., Vaidya, V. R., Mann, J., (2013b) Deep seismic image enhancement with the common reflection surface (CRS) stack method: evidence from the Aravalli-Delhi fold belt of northwestern India. Geophy. J. Int., 196 (2), 902-917.

Maurya, S., Montagner, J. P., Kumar, M. R., Stutzmann, E., Kiselev, S., Burgos, G., ... Srinagesh, D. ( 2016), Imaging the lithospheric structure beneath the Indian continent. J. Geophys. Res: Solid Earth, 121, 7450- 7468. https://doi.org/10.1002/2016JB012948.

Meissner, (1986). The Continental Crust: A Geophysical Approach. vol. 426. Academic, San Diego, CA.

Meen, J.K., Rogers, J.J.W. and Fullagar, P.D. (1992). Lead isotopic compositions in the Western Dharwar craton, southern India: evidence for distinct middle Archaean terrains in a Late Archaean craton. Geochim. Cosmochim. Acta, vol. 56, pp. 2455-2470.

Mishra, O. P., Kayal J. R., Chakrabortty G. K., Singh, O. P. and Ghosh, D., (2007a), Aftershocks investigation in Andaman-Nicobar islands of India and its seismotectonic implications, Bull. Seism. Soc. Amer. v. 97, no. 1A, p. S71-S85.

Mishra, O. P., Singh, O. P., Chakrabortty, G. K. and Kayal, J. R., (2007b), Aftershock investigation in Andaman-Nicobar Islands: An antidote to public panic? Seismol. Res. Letts., v. 78, no. 6, p. 591-600.

Molnar, P., P. England, and J. Martinod (1993), Mantle dynamics, uplift of the Tibetan Plateau, the Indian monsoon, Rev. Geophys., 31, $357-396$.

Murty A. S. N., Tewari H. C., Kumar, P., and Reddy P. R., (2005). Sub-crustal low velocity layers in central India and their implications, PAGEOPH, 162, 2409-2431.

Naqvi, S. M., and J. J. W. Rogers (1987), Precambrian Geology of India, Oxford Univ. Press, New York.

Naha, K., R. Srinivasan and S. Jayaram (1991), Sedimentological, structural and migmatitic history of the Archaean Dharwar tectonic province, southern India, Proceedings of the Indian Academy of Science (Earth Planetary Science), 100, 413- 433.

Narayanaswamy S., (1966). Tectonics of Cuddapah basin. Jour. Geol. Soc. India, 7, 33-50.

Patriat, P., and J. Achache (1984), India-Eurasia collision chronology has implications for crustal shortening and driving mechanism of plates, Nature, 311, 615 - 621 .

Polet, J., and D. L. Anderson (1995), Depth extent of cratons as inferred from tomographic studies, Geology, 23, 205-208.

Rajendra Prasad B., Tewari H. C., Vijaya Rao V., Dixit M. M. and Reddy P.R., (1998). Structure and tectonics of the Proterozoic Aravalli-Delhi Fold Belt in the northwestern India from Deep seismic reflection studies, Tectonophysics, 288,31-41.

Raju, K. A. K., T. Ramprasad, P.S. Rao, B.R. Rao, J. VargheseNew insights into the tectonic evolution of the Andaman basin, northeast Indian Ocean Earth Planet. Sci. Lett., 7024 (2004), pp. $1-18$.

Ramakrishnan, M., Viswanantha M. N. and Swami Nath J., (1976). Basement-cover relationship of peninsular gneiss with high-grade schist and greenstone belts of southern Karnataka. Jour. Geol. Soc. India, 17, 97-111.

Rao N.P. \& Kumar M.R. , (1997), Uplift and tectonics of the Shillong plateau, northeast India, J. Phys. Earth, 45, 167-176.

Rao, R. D., B. L. Narayana, S. N. Charan, and R. Natarajan (1991), $\mathrm{P}-\mathrm{T}$ conditions and geothermal gradients of gneiss-enderbite rocks: Dharmapuri area, Tamil Nadu, India, J. Petrol., 32(3), 539554.

Rao, Y. J. B., K. Naha, R. Srinivasan and K. Gopalan (1991), Geology, geochemistry and geochronology of the Archaean Peninsular Gneiss around Gorur, Hassan District, Karnataka, India, Proc. Indian Acad. Sci. Earth Planet Sci., 100, 399- 412.

Raval U., (1989). On hotspots, Meso-Cenozoic tectonics, and possible thermal networking beneath the Indian continent. In: Advances in Geophysical Research India, Ind. Geophys. Un., Hyderabad, 314-30.

Ray L., Senthil Kumar P., Reddy G. K, Roy S., Rao G. V., Srinivasan R. and Rao R. U. M., (2003). High mantle heat flow in a Precambrian granulite province: evidence from southern India. Jour. Geophys. Res. 108 (B2), 2084.

Reddy P. R., Chandrakala K., Prasad A. S. S. S. R. S and Rama Rao Ch., (2004). Lateral and vertical crustal velocity and density variation in the Cuddapah basin and adjoining Eastern Dharwarcraton. Current Science, 87, 1607-1614.

Reddy P. R., Murty P. R. K., Rao I. B. P., Prakash Khare, Kesava Rao G., Mall D. M., Koteswara Rao P., Raju S., Sridhar V. and Reddy M. S., (1995). Deep Crustal Seismic Reflection Fabric Pattern in Central India-Preliminary Interpretation, In: (S. Sinha-Roy and K. R. Gupta, Eds.), Continental crust of NW and Central India, Geol. Soc. India, Mem. 31, 537-544.

Rogers, J. J. W., and E. J. Callahan (1987), Radioactivity, heat flow and rifting of the Indian continental crust, J. Geol., 95, 829-836.

Rychert, C. A., and P. M. Shearer (2009), A global view of the lithosphere-asthenosphere boundary, Science, 324, 495-498, doi:10.1126/science.1169754.

Sarkar D., Chandrakala K., Padmavathi Devi P., Sridhar A. R, Sain K. and Reddy P. R., (2001). Crustal velocity of western Dharwar craton, South India, Jour. Geodyn. 31, 227-241.

Sarkar S. N., Gopalan K. and Trivedi J. R., (1981). New data on the geochronology of the Precambrians of Bhandara-Durg, Central India, Ind. Jour. Earth Sci., 8, 131-151.

Sinha-Roy S., (1999). Proterozoic sutures in Rajasthan, In: Proc. Seminar on Geology of Rajasthan: Status and Perspective, MLS University, Udaipur 87-100.

Sinha-Roy S., Malhotra G. and Guha D. B., (1995). A transect across Rajasthan Precambrian terrane in relation to geology, tectonics and crustal evolution of south central Rajasthan. In: (S. Sinha Roy and K. R. Gupta, Eds.), Continental crust of NW and Central India. Geol. Soc. India, Mem. 31, 63-89.

Suresh, G., S. Jain, and S. N. Bhattacharya (2008), Lithosphere of Indus block in the northwest Indian subcontinent through genetic 
algorithm inversion of surface-wave dispersion, Bull. Seismol. Soc. Am., 98, 1750-1755.

Tapponnier, P., X. Zhiqin, F. Roger, B. Meyer, N. Arnau, G. Wittlinger, and Y. Jingsui (2001), Oblique stepwise rise and growth of the Tibet Plateau, Science, 294, 1671 - 1677.

Tewari H. C. and Vijaya Rao V., (2003). Structure and tectonics of the Proterozoic Aravalli-Delhi geological province, NW Indian peninsular shield, In: (T. M. Mahadevan, B. R. Arora, K. R. Gupta, Eds), Indian Continental Lithosphere: emerging research Trends, Geol. Soc. India, Mem. 53, 57-78.

Tewari H. C., Divakar Rao V., Narayana B. L., Dixit M. M. Madhava Rao N., Murthy A. S. N., Rajendra Prasad B., Reddy P. R., Venkateswarlu N., Vijaya Rao V., Mishra D. C., and Gupta S. B., (1998). Nagaur-Jhalawar Geotransect across the Delhi/Aravalli Fold Belt in Northwest India, Jour. Geol. Soc. India, 52, 153161.

Tewari H. C., Dixit M. M. and Sarkar D., (1995). Relationship of the Cambay rift basin to the Deccan volcanism. Jour. Geodyn., 20, 85-95.

Tewari H. C., Rajendra Prasad B., Vijaya Rao V., Reddy P.R., Dixit M.M. and Rao M. N.,(1997b). Crustal Reflectivity Parameter for Deciphering the Evolutionary Processes across the Proterozoic Aravalli-Delhi fold belt, Jour. Geol. Soc. India, 50, 779-785.

Tewari H. C., Vijaya Rao V. and Rajendra Prasad B., (2000). Tectonic significance of seismic reflectivity patterns: a study from the NW Indian Shield. In: (M. Deb, Ed.), Crustal Evolution and Metallogeny in the north-western Indian Shield, Narosa Publishing house, New Delhi, 189-202.

Tewari, H. C., A. S. N. Murty, P. Kumar, and A. R. Sridhar (2001), A tectonic model of the Narmada region, Curr. Sci., 80(7), 873878.

Tewari, H. C., and Kumar, P., Deep Seismic Sounding Studies in India and its Tectonic Implications, In: Geophysics: Window to Indian Geology, Ed. Mita Rajaram, Virtual Explorer, 12,30-54, http://virtualexplorer.com.au/journal/2003/12], 2003.

Tewari, H. C., Prasad, R. B., Kumar, P., Structure and Tectonics of the Indian Continental Crust and Its Adjoining Region. p. 266, ISBN: 9780128136850, Elsevier, 2018.

Tiwari, V. M., M. Ravi Kumar, and D. C. Mishra (2013), Long wavelength gravity anomalies over India: Crustal and lithospheric structures and its flexure, J. Asian Earth Sci., 70-71, 169-178.

Uma Devi, E., Kumar, P., Kumar, M. R., , (2011) Imaging the

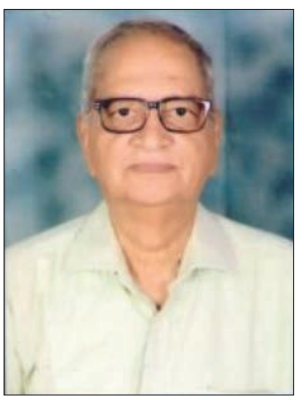

Harish C. Tewari earned his M. Sc. in physics from the Agra University and $\mathrm{PhD}$ from the Indian Institute of Technology Indian School of Mines, Dhanbad. His field of interest has been crustal seismic studies in India. He was employed by the CSIRNational Geophysical Research Institute, Hyderabad for 30 years and continue as Emeritus Scientist after retirement. He has been awarded the National Mineral Award of the Government of India for excellence in geophysics and the L.N. Kailasam gold medal by the Indian Geophysical Union.
Indian lithosphere beneath Eastern Himalayan region. Geophys. J. Int., Vol. 187, 631-641, doi: 10.1111/j.1365-246X.2011. 05185.x.

Uma Devi, E., P. Kumar, and M. R. Kumar (2011), Imaging the Indian lithosphere beneath Eastern Himalayan region, Geophys. J. Int., 187, 631-641, doi:10.1111/j.1365-246X.2011.05185.x.

Vijaya Rao V. and Rajendra Prasad B., (2006). Structure and evolution of the Cauvery Shear Zone system, Southern Granulite Terrene, India: Evidence from deep seismic and other geophysical studies, Gondwana Research, 10, 29-40.

Vijaya Rao V. and Reddy P.R., (2002). A Mesoproterozoic Supercontinent: Evidence from the Indian Shield, In: (J. J. W. Rogers and M. Santosh, Eds.), Special volume on Mesoproterozoic Supercontinent, Gondwana Research, 5, 63-74.

Vijaya Rao V., Rajendra Prasad B., Reddy P. R. and Tewari H. C., (2000). Evolution of Proterozoic Aravalli-Delhi Fold Belt in the northwestern Indian Shield from Seismic studies, Tectonophysics, 327, 109-130.

Vijaya Rao V., Sain K., Reddy P. R. and Mooney W. D., (2006). Crustal structure and tectonics of the northern part of the Southern Granulite terrane, India, Earth Plan. Sci. Let., 251, 90-103.

Watts, A. B., J. H. Bodine, and N. M. Ribe (1980), Observations of flexure and the geological evolution of the Pacific Ocean basin, Nature, 283, 532-537.

White R. S. and McKenzie D. P., (1989). Magmatism at rift zones: the generation of volcanic continental margins and flood basalts. Jour. Geophys. Res., 94, 7685-7729.

Willett SD, Beaumont C (1994), Subduction of Asian lithospheric mantle beneath Tibet inferred from models of continental collision. Nature 369(6482):642-645.

Yedekar D. B., Jain S. C., Nair K. K. K. and Dutta K. K., (1990). The Central Indian Collision Suture, In: Precambrian of Central India, Spl. Publ. Geol. Surv. India, Nagpur. 28, pp. 1-43.90.

Zhao, J., Yuan, X., Liu, H., Kumar, P., Pei, S., Kind, R., Zhang, Z, Teng, J., Xing Gao, L. D., Xu, D., Wang, W., The boundary between the Indian and Asian plates below Tibet. Proc. of the Nat. Acad. Sci., doi/10.1073/pnas.1001921107, 22, 107, 25, 2010.

Zhao, W., Kumar, P., Mechie, J., Kind, R., Meissner, R., Wu, Z., Shi, D., Su, H., Xue, H., Karplus, M., Tilmann, F., Tibetan plate overriding the Asian plate in central and northern Tibet, doi:10.1038/ngeo1309, Nat. Geoscience 4, 12, 870-873. doi:10.1038/ngeo1309, December, 2011.

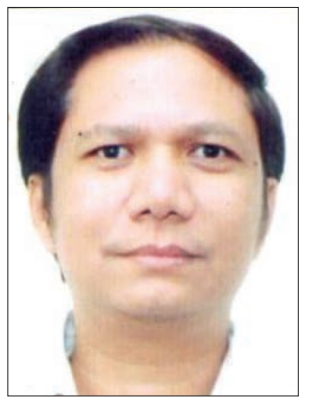

Prakash Kumar is a scientist on CSIRNational Geophsical Reserch Institute. He earned his M.Sc. (Tech) from Indian Institute of Technology - Indian School of Mines, Dhanbad and received his $P h D$ in geophysics from Osmania University. His research interests include Theoretical and computational seismology. He is a recipient of CSIR- Young Scientist Award, Krishnan Medal (from Indian Geophysical Union), National Geoscience Award (Ministry of Mines) and Anni Talwani Prize (from Indian Geophysical Union). 